\title{
Metabolomic Identification of Anticancer Metabolites of Australian Propolis and Proteomic Elucidation of Its Synergistic Mechanisms with Doxorubicin in the MCF7 Cells
}

\author{
Muhammad A. Alsherbiny ${ }^{1,2, *(\mathbb{D})}$, Deep J. Bhuyan ${ }^{1, *} \mathbb{C}$, Ibrahim Radwan ${ }^{3}$, Dennis Chang ${ }^{1}$ and Chun-Guang $\mathrm{Li}^{1, *}$ \\ 1 NICM Health Research Institute, Western Sydney University, Penrith, NSW 2751, Australia; \\ D.Chang@westernsydney.edu.au \\ 2 Department of Pharmacognosy, Faculty of Pharmacy, Cairo University, Cairo 11562, Egypt \\ 3 Faculty of Science and Technology, University of Canberra, Canberra, ACT 2617, Australia; \\ ibrahim.radwan@canberra.edu.au \\ * Correspondence: Muhammad.alsherbiny@pharma.cu.edu.eg (M.A.A.); \\ d.bhuyan@westernsydney.edu.au (D.J.B.); c.li@westernsydney.edu.au (C.-G.L.)
}

check for updates

Citation: Alsherbiny, M.A.; Bhuyan, D.J.; Radwan, I.; Chang, D.; Li, C.-G. Metabolomic Identification of

Anticancer Metabolites of Australian Propolis and Proteomic Elucidation of Its Synergistic Mechanisms with Doxorubicin in the MCF7 Cells. Int. J. Mol. Sci. 2021, 22, 7840. https:// doi.org/10.3390/ijms22157840

Academic Editor: Siyaram Pandey

Received: 4 June 2021

Accepted: 19 July 2021

Published: 22 July 2021

Publisher's Note: MDPI stays neutral with regard to jurisdictional claims in published maps and institutional affiliations.

Copyright: (c) 2021 by the authors. Licensee MDPI, Basel, Switzerland. This article is an open access article distributed under the terms and conditions of the Creative Commons Attribution (CC BY) license (https:// creativecommons.org/licenses/by/ $4.0 /)$.

\begin{abstract}
The combination of natural products with standard chemotherapeutic agents offers a promising strategy to enhance the efficacy or reduce the side effects of standard chemotherapy. Doxorubicin (DOX), a standard drug for breast cancer, has several disadvantages, including severe side effects and the development of drug resistance. Recently, we reported the potential bioactive markers of Australian propolis extract (AP-1) and their broad spectrum of pharmacological activities. In the present study, we explored the synergistic interactions between AP-1 and DOX in the MCF7 breast adenocarcinoma cells using different synergy quantitation models. Biochemometric and metabolomics-driven analysis was performed to identify the potential anticancer metabolites in AP-1. The molecular mechanisms of synergy were studied by analysing the apoptotic profile via flow cytometry, apoptotic proteome array and measuring the oxidative status of the MCF7 cells treated with the most synergistic combination. Furthermore, label-free quantification proteomics analysis was performed to decipher the underlying synergistic mechanisms. Five prenylated stilbenes were identified as the key metabolites in the most active AP-1 fraction. Strong synergy was observed when AP-1 was combined with DOX in the ratio of 100:0.29 $(w / w)$ as validated by different synergy quantitation models implemented. AP-1 significantly enhanced the inhibitory effect of DOX against MCF7 cell proliferation in a dose-dependent manner with significant inhibition of the reactive oxygen species $(p<0.0001)$ compared to DOX alone. AP-1 enabled the reversal of DOX-mediated necrosis to programmed cell death, which may be advantageous to decline DOX-related side effects. AP1 also significantly enhanced the apoptotic effect of DOX after $24 \mathrm{~h}$ of treatment with significant upregulation of catalase, HTRA2/Omi, FADD together with DR5 and DR4 TRAIL-mediated apoptosis $(p<0.05)$, contributing to the antiproliferative activity of AP-1. Significant upregulation of proapoptotic p27, PON2 and catalase with downregulated anti-apoptotic XIAP, HSP60 and HIF-1 $\alpha$, and increased antioxidant proteins (catalase and PON2) may be associated with the improved apoptosis and oxidative status of the synergistic combination-treated MCF7 cells compared to the mono treatments. Shotgun proteomics identified 21 significantly dysregulated proteins in the synergistic combination-treated cells versus the mono treatments. These proteins were involved in the TP53/ATM-regulated non-homologous end-joining pathway and double-strand breaks repairs, recruiting the overexpressed BRCA1 and suppressed RIF1 encoded proteins. The overexpression of UPF2 was noticed in the synergistic combination treatment, which could assist in overcoming doxorubicin resistance-associated long non-coding RNA and metastasis of the MCF7 cells. In conclusion, we identified the significant synergy and highlighted the key molecular pathways in the interaction between AP-1 and DOX in the MCF7 cells together with the AP-1 anticancer metabolites. Further in vivo and clinical studies are warranted on this synergistic combination.
\end{abstract}


Keywords: doxorubicin; breast cancer; breast adenocarcinoma; MCF7; propolis; synergy; proteomics; metabolomics; apoptosis

\section{Introduction}

Doxorubicin (DOX), also known as Adriamycin (a type of anthracycline), is a frontline cytotoxic drug used in numerous chemotherapeutic protocols for various cancer types, including breast cancer [1-6]. Despite its broad-spectrum cytotoxic effects [3,7-14], DOX is associated with several severe side effects, including cardiotoxicity, hepatotoxicity, nephrotoxicity and fertility issues. In particular, DOX has been reported to cause lethal cardiomyopathy in cancer patients through free radical-induced oxidative stress and excessive production of reactive oxygen species $[15,16]$. The type 1 cardiac damage caused by a cumulative dose of doxorubicin is irreversible [17]. Dose-dependent cardiotoxicity of DOX is mediated via interference with DNA replication and transcription, which limits its therapeutic application $[15,18]$. Additionally, the development of drug resistance of the cytotoxic agents such as DOX poses a considerable challenge in cancer therapy $[3,19,20]$. Therefore, more efforts are being directed toward a combination therapy or the development of targeted drug delivery formulations to increase DOX therapeutic potential or alleviate adverse effects [11,21-30].

Combination therapies have been widely adopted to overcome the limitations of the monotherapy regimens and perhaps a compelling approach in cancer treatment that offers benefits via patient-to-patient variability even without drug synergy [31]. The combination strategy may help overcome cancer complexity via targeting multiple pathophysiological components of the disease [32,33]. Combination therapies target different cellular pathways and block cancer evolution escape mechanisms and drug resistance [34]. However, the lack of a gold standard synergy quantitation model warrants considering different synergy metrics to understand the interactions of the individual components in the combination therapy. Different assumptions and limitations in various metrics fueled the persistence of historical rifts among these discording synergy models [35,36]. Various synergy metrics, including Loewe additivity [37], Zero independence potency (ZIP) [38], highest single agent (HSA) [39], and Bliss independence [40], displayed a modest Pearson and Spearman correlation with strong disagreement instances when calculated for $\mathrm{O}^{\prime} \mathrm{Neil}$ anticancer combination dataset $[36,41,42]$. Additionally, substantial disagreements reported when correlating synergy scores originated from different datasets [36]. Therefore, synergistic combinations of interest should be validated against different models before further studies to be considered.

A growing body of evidence demonstrates the advantages of the concurrent administration of herbal medicines with chemotherapy regimens [29,43-48] not only as cytotoxic agents but also as an antidote for chemotherapy-induced multi-organ toxicities. Propolis, for example, is a resinous substance accumulated by the bees from different types of plants with a broad spectrum of activities, including antioxidant, anti-inflammatory, antimicrobial and anticancer properties [49-52]. Australian propolis possesses superior pharmacological activity with a unique chemical fingerprint compared to its Brazilian and Chinese counterparts [49], presumably due to Australia's megadiverse and unique biodiversity. Previously, prenylated stilbenes isolated from Kangaroo Island propolis [53,54] showed promising antioxidant and cytotoxic properties against 60 human tumour cell lines (NCI-60) with the $\mathrm{IC}_{50}$ values $0.68-2.7 \mu \mathrm{M}$ against the MCF7 cells. Prenylated-flavanones with potential antimicrobial and anticancer activity have also been previously isolated from propolis samples collected worldwide [55-62]. As novel drug development entails ample resources and time, combining pre-existing anticancer drugs with natural product-based adjuvants such as propolis or its metabolites could be a promising and economical approach to enhance the efficacy and/or reduce the side effects of chemotherapy. 
The present study was designed to assess the synergistic interactions between Australian propolis (AP-1) and DOX against the MCF7 breast adenocarcinoma cell line using different synergy quantification models. Furthermore, we evaluated the molecular mechanisms involved in the most synergistic combination by analysing the apoptotic profile and oxidative status of the treated MCF7 cells along with the comprehensive biochemometric and metabolomic-driven identification of AP-1 anticancer metabolites. Label-free quantification proteomics analysis was conducted to decipher the complex molecular pathways of the underlying synergistic mechanisms.

\section{Results and Discussion}

\subsection{Biochemometric and LCMS Metabolomic Identification of Cytotoxic Metabolites of AP-1}

We recently evaluated the AP-1 for the potential marker metabolites compared to Chinese and Brazilian propolis samples. In addition, seven common phenolics, including $\mathrm{CAPE}$, artepillin $\mathrm{C}$, galangin, chrysin, pinocembrin, daidzein and naringenin, were quantified in AP-1 using HPLC [49]. In the present study, almost no cell death was observed for normal macrophages (RAW 264.7) upon treatment with AP-1 and its DOX combination up to $200 \mu \mathrm{g} \mathrm{mL}^{-1}$. The $\mathrm{IC}_{50}$ value of $177.2 \mu \mathrm{g} \mathrm{mL}^{-1}$ was observed against MCF10A normal breast cell line for AP- 1 with a $95 \%$ confidence interval of 150.5 to $215.7 \mu \mathrm{g} \mathrm{mL}^{-1}$ (Figure S1). AP-1 showed an MCF7 selectivity index of 2.81 and $>2.85$ compared with MCF10A and RAW 264.7 cells, respectively. Additionally, a growing body of evidence supports that propolis is generally considered safe [63-66].

AP-1 was subjected to C18 preparative HPLC fractionation into five fractions (A001A005), and their antiproliferative activity in the MCF7 breast adenocarcinoma cells was evaluated using alamarBlue assay (Figure 1D). The fraction A003 exhibited the most significant cytotoxicity against the MCF7 cells with an $\mathrm{IC}_{50}$ value of $10.62 \pm 0.88 \mu \mathrm{g} \mathrm{mL}$ compared to the other four fractions.

The LCMS metabolomic profile of A003 was compared with other less active fractions to spot the marker metabolites responsible for the antiproliferative effect. Statistically significant metabolites (ANOVA, $p \leq 0.05$ and fold change $\geq 2$ ) were subjected to OPLS-Da analysis to identify the discriminating metabolites of the active fraction against others. Nine metabolites were recognized and putatively identified. Notably, good discrimination among propolis fractions was preserved, as shown in the score plots of PCA analyses of the significant metabolome and OPLS-DA-filtered metabolites (Figure 1A,B), despite the features were massively reduced from 1831 to 9 . All precursor ions, adducts, fragments, and collision cross-sections (CCS) calculated from ion mobility with the retention time and mass error are listed in Table S1. Five prenylated stilbenes (compounds 1, 2, 4, 5 and 7) were putatively identified (Figures 1 and 2 and Table S1) with two prenylated flavonoids (flavanone and chalcone) and two undefined triterpenes. The compounds 4, 5 and 7 were previously isolated from Kangaroo Island propolis, South Australia [53,54] and promising antioxidant and cytotoxic properties were reported against a panel of 60 human tumour cell lines (NCI-60) with the $\mathrm{IC}_{50}$ values of $0.68-2.7 \mu \mathrm{M}$ against the MCF7 cells. Prenylatedflavanones (e.g., compound 9) have also been previously isolated from propolis samples collected from Egypt, Nigeria, Brazil, Indonesia, Japan, Taiwan, Australia and Solomon Islands [55-62] with potential antimicrobial and anticancer activities. Another flavonoid subclass, chalcone, was tentatively identified (compound 3), sharing common fragments with compound 7 , including $m / z$ 323.1281, 255.0615 and 254.0567. 

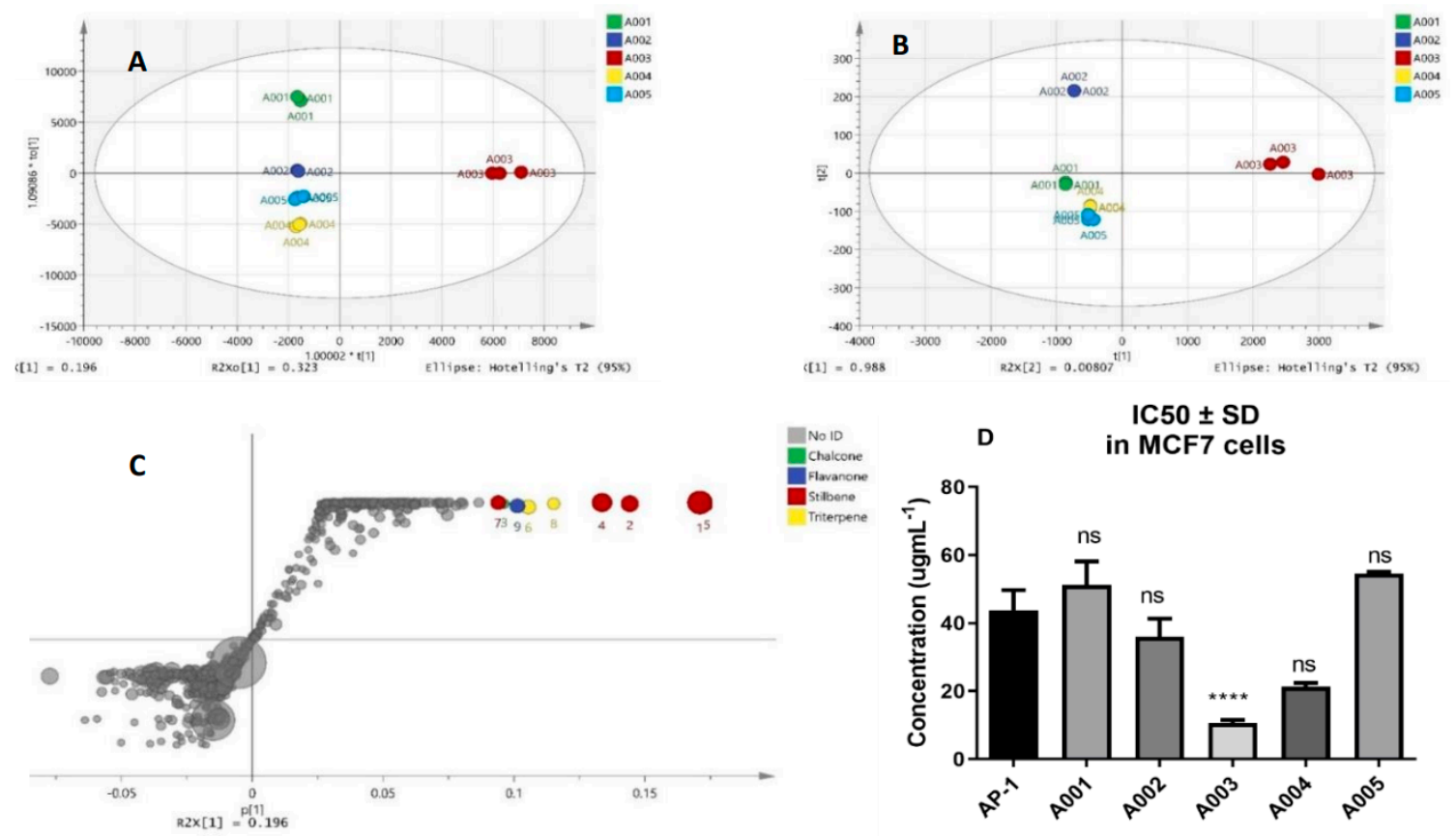

Figure 1. Biochemometric and LCMS metabolomic-driven identification of anticancer metabolites in AP-1 against the MCF7 breast adenocarcinoma cells. (A) Score plot of the UPLC-MS $(m / z 50-1200)$ principal component analyses (PCA) of the significant metabolome of propolis fractions as described by vectors of principal component 1 and 2, (B) Score plot of the UPLC-MS ( $m / z$ 50-1200) OPLS-DA selected metabolites of propolis fractions as described by vectors 1 and 2. (C) Loading scatter S-plot of the UPLC-MS OPLS-DA analysis of significant AP-1 metabolites, comparing the most active fraction with less active ones, with a legend indicating its chemical class and feature size reflects its abundance in the crude extract. (D) Average concentration inhibiting 50\% of the MCF7 cells $\left(\mathrm{IC}_{50}\right)$ upon treatment with AP-1 and its fractions for $72 \mathrm{~h}(n=3$, ns $=$ non-significant, ${ }^{* * * *}=$ statistically significant compared to the propolis extract at $p<0.0001$ via one-way ANOVA with Dunnet's correction of multiple comparisons).

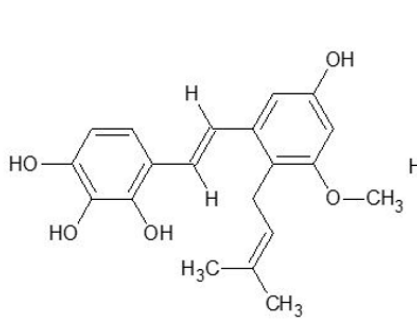

1;

5,2',3',4'-tetrahydroxy3-methoxy-2-prenyl-(E)-stilbene

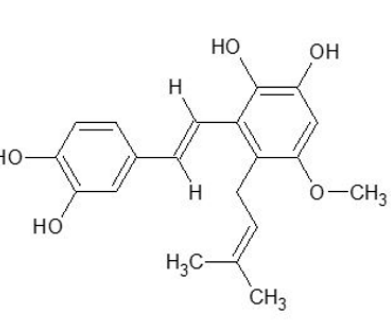

2;

5,6,3',4'-tetrathydroxy-3-methoxy2-prenyl-(E)-stilbene

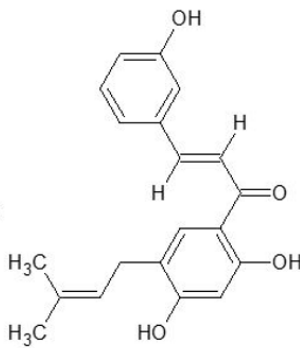

3;

Prenyl-trihydroxy-chalcone

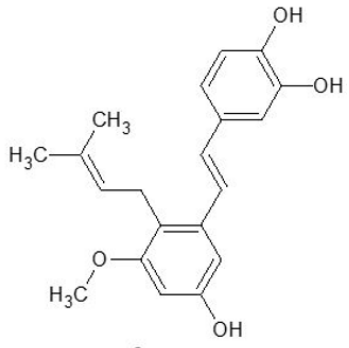

4; prenyl- (E)-stilbene

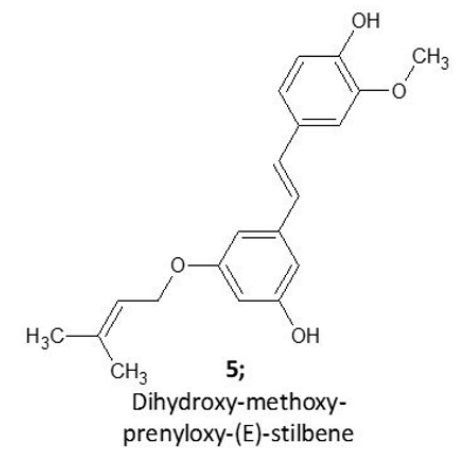

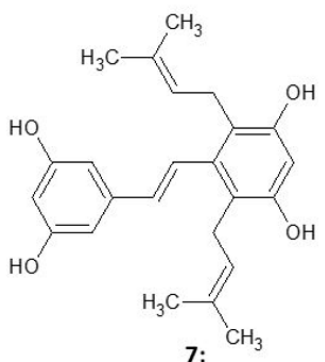

(E)-2,6-bis(3-methyl-2-buten-1-yl)$3,3^{\prime}, 5,5^{\prime}$-tetrahydroxystilbene<smiles>CC(C)=CCC/C(C)=C/Cc1c(O)cc2c(c1O)C(=O)C[C@@H](c1ccc(O)c(O)c1)O2</smiles>

9;

Geranyl-tetrahydroxyflavanone (propolin C/D/F)

Figure 2. Putative LC-MS identified metabolites in the AP-1 extract with potential anticancer activity against the MCF7 cells. 
Various pharmacological effects of the prenylated chalcones (e.g., compound 3) have been reported in the literature, including the anticancer activity [67-71]. Compounds $\mathbf{1}$ and $\mathbf{2}$ differ from previously isolated and fully characterised prenyl stilbenes such as compounds 4 and 5 in one extra oxygen atom $(15.99-16.00 \mathrm{Da})$ and share their characteristic fragments at $m / z 188.0480$, and 144.0580. Therefore, the hydroxylated candidates of isolated prenyl stilbenes $\left(\mathrm{C}_{20} \mathrm{H}_{22} \mathrm{O}_{4}\right)$ from AP-1 were prepared, and Competitive Fragmentation Modeling-ID (CFMID 4.0) was utilised for candidate ranking with 10 ppm mass tolerance and both Dice and DotProduct scoring functions were considered [72]. The highest scores were allocated to tetra-hydroxy-methoxy-prenyl stilbenes $\left(5,2^{\prime}, 3^{\prime}, 4^{\prime}\right.$-tetrahydroxy-3methoxy-2-prenyl-(E)-stilbene and 5,6,3', $4^{\prime}$-tetra-hydroxy-3-methoxy-2-prenyl-(E)-stilbene) upon CFMID-matching with the fragmentation pattern of compound $\mathbf{1}$ and $\mathbf{2}$, respectively (Figure 2).

\subsection{Synergy Quantification of AP-1 and DOX Combinations against the MCF7 Breast Adenocarcinoma Cells}

As there is no gold standard synergy model [42] to quantify the complex synergistic interactions between drugs, we implemented multiple synergy quantification metrics to gain a comprehensive understanding of the potential synergistic interactions between AP-1 and DOX. The Combination Index (CI) model was used to quantify the cytotoxic interactions between AP-1 and DOX in the MCF7 cells after $72 \mathrm{~h}$ of treatment. The $\mathrm{CI}<1$ and $\mathrm{CI}>1$ indicate synergy and antagonism, respectively, whereas additivity is indicated by $\mathrm{CI}=0$ [73]. AP-1 and DOX were combined in ratios from 100:2.6 to 100:0.03 w/w, and CompuSyn-calculated CI values at 50, 75, 90, 95 and 97\% inhibitory concentrations were reported in Table 1. Each combination was represented by IDs (e.g., PDOX19), where the last two digits indicate the corresponding combination ratio $w / w$ of AP-1 and DOX, respectively (Table 1). A strong synergy was observed for the PDOX55 combination (100:0.29 $w / w)$ in all modelled inhibitory concentrations (Figure S2) where the first dose of $100 \mu \mathrm{g} \mathrm{mL}{ }^{-1} \mathrm{AP}-1$ and $0.29 \mu \mathrm{g} \mathrm{mL}{ }^{-1}$ DOX showed the CI value of 0.11 with $94 \%$ cellgrowth inhibition. The same data of the AP- 1 and DOX combinations were imported to the DrugComb webserver. In addition, checkerboard assay was used to combine DOX and AP-1 in 1:10 and 1:2 serial dilutions, respectively. This enabled synergy quantification in Loewe, ZIP, BLISS, HSA and S synergy score models in addition to the CSS to gain a comprehensive understanding of the synergistic interactions between AP-1 and DOX to inhibit the MCF7 cells.

Unlike synergy that captures the drug interactions, the combination sensitivity score (CSS) measures the efficacy, and its negligence may lead to biased synergistic combinations [74]. The CSS is a robust metric derived from the relative $\mathrm{IC}_{50}$ value and area under the drug combination dose-response curve and was developed for efficacy quantification of drug combinations [75]. Figure 3 and Table 1 summarised the sensitivity and interactions between AP- 1 and DOX checkerboard combinations. Notably, potential synergy was observed between AP-1 and DOX in most models with a promising CSS value. Interestingly, both CSS and S scores were able to capture sensitivity and synergy, respectively, for both CI-model data and its combination when reanalysed in DrugComb, unlike other synergy metrics. 
Table 1. Synergy quantitation of AP-1 and DOX combinations against the MCF7 breast adenocarcinoma cells.

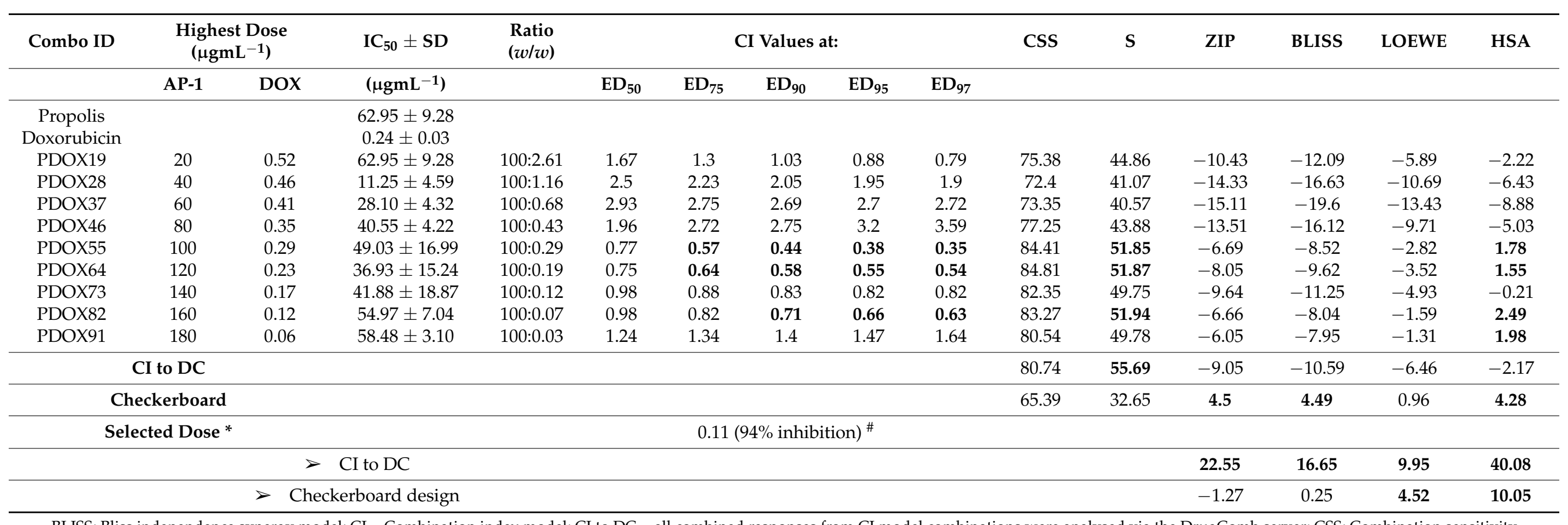

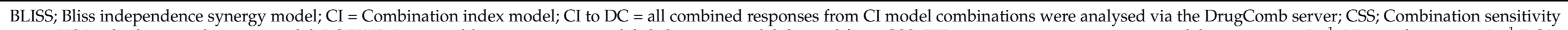

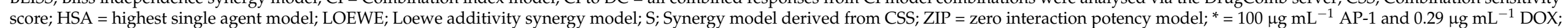

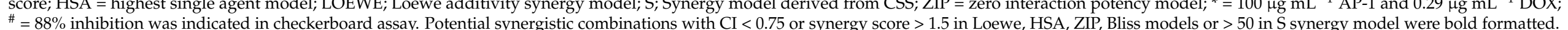




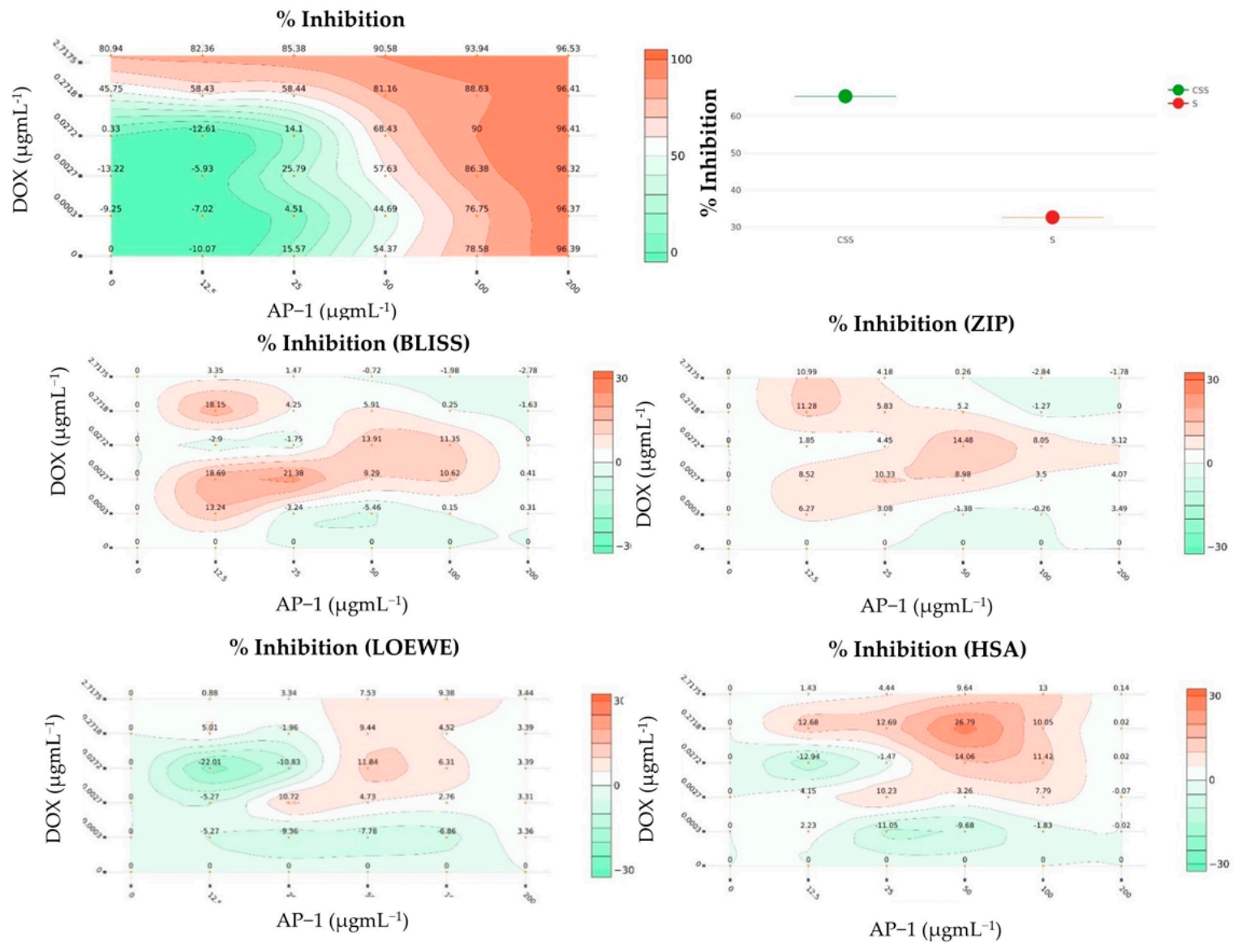

Figure 3. Synergy and sensitivity quantitation of AP-1 in combination with DOX against the MCF7 cells in a checkerboard assay.

The reprocessing of CI-model data of PDOX combos or their combined responses via DrugComb showed a notable antagonism in all synergy models except for the S synergy score (The increased \% inhibition when two drugs are additive at their relative $\mathrm{IC}_{50}$ ). However, strong correlation to the CI-model derived interactions were indicated by Pearson's correlation $r$ values $(-0.75:-0.96)$, where the negative correlation signalled the different scaling where the synergistic potential of CI-model should be $<0$ and that for DrugComb synergy scores should be $>0$ (Table S2 and Figure 4). Furthermore, the HSA model was able to capture the most synergistic combinations such as PDOX55, PDOX82 and PDOX64. Nevertheless, the HSA score for PDOX91 was not in agreement with that of the CI model. Notably, different synergy metrics, including Loewe, ZIP, HSA, and Bliss, displayed a modest correlation with strong disagreement instances when calculated for $\mathrm{O}^{\prime} \mathrm{Neil}$ anticancer combination dataset (22,737 unique combinations) [36,41,42]. Besides, substantial disagreements reported when correlating synergy scores originated from different datasets [36]. So, the selected synergistic dose for subsequent studies was validated against different models (Table 1).

\subsection{Inhibition of Reactive Oxygen Species (ROS) Production in the MCF7 Cells after Mono and Combined Treatments with AP-1 and DOX}

Elevated ROS plays a key role in cancer pathogenesis and contributes to tumour metastasis [76,77]. We studied the ROS production in the MCF7 cells treated with AP-1, DOX and their most synergistic combination (as per the tested synergy matrices) in a half and quarter of the selected synergistic dose to avoid any cell death-related ROS depletion. No significant differences in the viability of the MCF7 cells compared to the negative control 
was indicated for the halved and quartered doses of AP-1, DOX and their combination (Figure 5b).

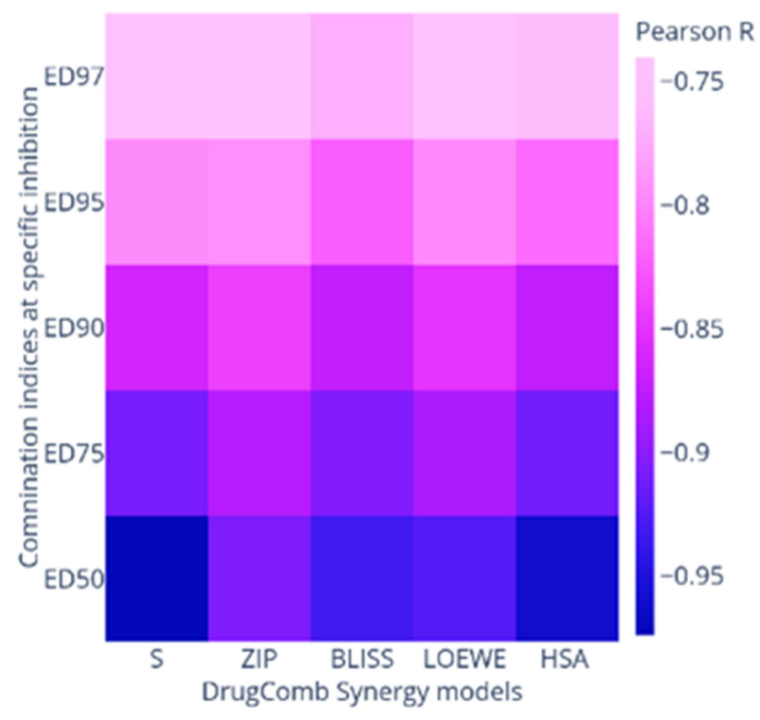

Figure 4. Pearson's correlation $r$ values among different synergy quantitation metrics.
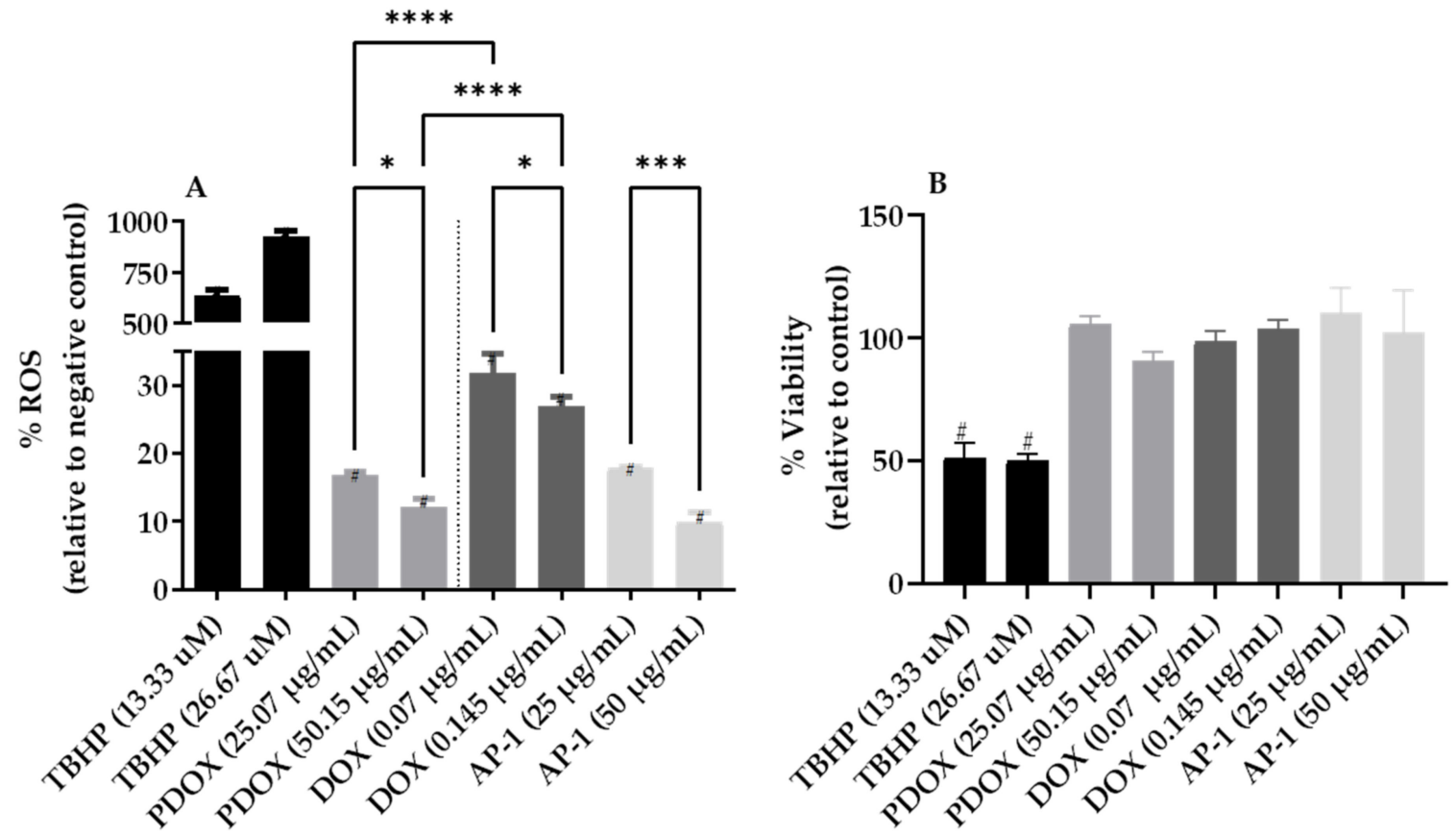

Figure 5. Relative ROS production in MCF7 (A) and its percentage viability (B) compared to the negative control, upon treatment with Australian propolis (AP-1), doxorubicin (DOX), their synergistic combination (PDOX) and the positive control tert-Butyl hydroperoxide (TBHP). Values expressed as mean \pm standard deviation (SD) ( $n=3)$, One-way ANOVA was used for multiple comparisons, \#; statistically significant relative to negative control $(p<0.0001),{ }^{*} ; p<0.05,{ }^{* * *} ; p<0.001$, ****; $p<0.0001$.

Furthermore, the ROS production in the MCF7 cells was significantly decreased by AP-1, DOX and their combinations compared to the negative control in a dose-dependent manner. In addition, the combination significantly enhanced the ROS inhibitory effect of DOX $(p<0.0001$; Figure 5a).

The elevated ROS production and survival dependency were indicated in triplenegative breast cancer cells, which were more sensitive to antioxidant treatments compared 
to positive estrogen receptor (ER+) cell lines [78]. However, improved MCF7 sensitivity to DOX in combination with an antioxidant such as vitamin $C$ was reported in both noncytotoxic and moderately cytotoxic vitamin $C$ doses [79]. The same enhancement was reported for DOX with vitamin C against the triple-negative MDA-MB-231 cell line which contradicts the finding of Sarmiento-Salinas, et al. [78]. While the ROS decline after AP-1 treatment can be attributed to its antioxidant properties, the DOX-mediated ROS decline observed in our study is inconsistent with the well-documented DOX-induced ROS in cancers and normal cells $[80,81]$. This may be ascribed to the low DOX doses $(0.145$ and $0.07 \mu \mathrm{g} \mathrm{mL}^{-1}$ ) implemented in our study compared to the higher DOX doses reported in the literature or shorter exposure time $(4 \mathrm{~h})$. For instance, $40 \mu \mathrm{g} \mathrm{mL}^{-1}$ of DOX after $8 \mathrm{~h}$ of treatment was shown to increase the ROS production in the MCF7 cells [82]. However, a $0.3-5.0 \mu \mathrm{M}$ plasma concentration of DOX is commonly used clinically with a general initial plasma concentration of 1-2 $\mu \mathrm{M}$ DOX can decline quickly to $25-250 \mathrm{nM}$ level within $1 \mathrm{~h}$ [81]. Therefore, studies that utilise higher doses $(>1-2 \mu \mathrm{M})$ of DOX may not accurately reflect the clinical implementation of DOX [81]. In addition, the observed ROS decline in the DOX-treated MCF7 cells in our study may indicate the predominance of DNA synthesis inhibition mechanism rather than a free radical generation with the studied doses. Another study observed no ROS-mediated DCF fluorescence in the PA-1 human ovarian teratocarcinoma cells treated with $0.5 \mu \mathrm{M}$ DOX compared to the negative control where DOX did not show $\mathrm{H}_{2} \mathrm{O}_{2}$ generation to any extent in the PA-1 cells unlike in the Bovine Aorta Endothelial Cells (BAECs) [83]. The findings of that study were also inconsistent with the literature, however, the authors did not perform fluorescence quantification to measure any ROS decline in the PA-1 cells [83] unlike our study. We used the same dye and same exposure time of $4 \mathrm{~h}$ but with lower DOX doses.

Notably, antioxidants have differential effects on DOX-mediated apoptosis and caspase 3 activity in normal and tumour cells where apoptosis and caspase 3 activity declined in BAEC and ARCM normal cells and increased in the MCF-7 and the PA-1 cells [83], which support the use of AP-1 in combination with DOX. Further validations are necessary to support any biphasic dose- and/or time-dependent ROS production profile of DOX. The complex, context-dependent and paradoxical roles of ROS in cancer are well-reported in the literature with ROS surge linked to both the tumour proliferative processes and a potential avenue to selectively target cancer cells [84]. For example, piperlongumine [85] and blueberry extracts [86] selectively induced ROS in cancer cells, but not in the normal MCF10A cells. Section 2.5 will explore the dysregulated apoptotic antioxidant proteins in the MCF7 cells upon the combination and mono treatments and their paradoxical effects.

\subsection{Flow Cytometric Analysis of Apoptosis in the MCF7 Cells Using Annexin V-CF Blue and 7AAD}

Synergistic interactions between anticancer drugs are desirable traits to enhance efficacy, reduce dosage and mitigate the subsequent adverse effects. This strategy is also promising in overcoming the escape mechanisms and drug resistance of cancer [32-34]. In this study, we evaluated the apoptotic profiles of the MCF7 cells using flow cytometry after treatment with AP-1 $\left(100 \mu \mathrm{g} \mathrm{mL}{ }^{-1}\right)$, DOX $\left(0.29 \mu \mathrm{g} \mathrm{mL}^{-1}\right)$ and their most synergistic combination PDOX55 (At half-dose; $50 \mu \mathrm{g} \mathrm{mL}^{-1} \mathrm{AP}-1$ and $0.15 \mu \mathrm{g} \mathrm{mL}{ }^{-1}$ DOX). Simultaneous evaluation of the live, early to late apoptotic and necrotic cell populations was carried out to observe whether the most synergistic combination had any effect on apoptotic pathways of the MCF7 cells compared to mono treatments. The half-dose of the most synergistic combination was implemented to statistically evaluate the effects of the combined treatment as higher doses might lead to elevated apoptosis via additive effect, however with side effects. Annexin $\mathrm{V}$ is commonly used to detect apoptosis by binding to the phosphatidylserine (PS) phospholipids on the cell surface. PS is translocated to the outer surface of cells during apoptosis [87]. Conversely, 7-AAD is a fluorescent dye that intercalates in double-stranded DNA with a high affinity for guanine-cytosine residues and is used as a DNA fluorescent marker in flow cytometry and fluorescence microscopy [88,89]. 
In apoptotic analysis, Annexin $\mathrm{V}$ and 7-AAD are combined to distinguish necrotic cells from early and late apoptotic cells. The PerCP and Pacific blue channels were utilised for Annexin V and 7-AAD in this study as emission spectra of these dyes do not overlap, so no compensation is necessary (Figure S3). After $24 \mathrm{~h}$, significant differences among the live and late apoptotic cell populations were observed in the mono and combined treatments compared to the vehicle control $(p<0.0001 ; n=4)$ (Figure 6, Figure S4, and Table S3). The AP-1 treatment led to a significant increase in the early and late apoptotic cells (43.02 \pm 5.46 and $43.53 \pm 12.89$, respectively; $p<0.0001$ ), whereas the DOX treatment exhibited a significant increase of the necrotic cells $(83.85 \pm 3.15 \% ; p<0.0001)$ compared to the vehicle control (Figure 6B, Table S3). Interestingly, the synergistic combination at its half-dose significantly increased the percentage of late apoptotic cells to $87.59 \pm 7.44 \%$ compared to the vehicle control and the mono treatments. In addition, a significant reduction of the necrotic cells $(4.25 \pm 4.04 \% ; p<0.0001)$ was observed for the synergistic combination compared to DOX alone. The number of necrotic cells in the combined treatment was statistically similar to that of the vehicle control, which might indicate the ability of the synergistic combination to shift DOX-mediated necrosis to apoptosis. The observed necrotic to apoptotic shift in the synergistic combination may be attributed to the antioxidant profile of AP-1 [49]. The antioxidant-related apoptotic proteins in the MCF7 cells will be discussed in the Apoptotic Proteome Array analyses (Section 2.5). The necrotic to apoptotic shift has been reported earlier in the literature by other antioxidants $[90,91]$ and was observed in the MCF7 cells treated with DOX and all-trans retinoid acid [92]. Sugimoto, et al. studied the DOX-induced necrosis of Jurkat cells and its acceleration and conversion by antioxidants to apoptosis [93]. Collectively, AP-1 enhanced the anticancer activity of DOX by promoting apoptosis and reducing necrosis which might be advantageous to reduce the DOX-mediated side effects.

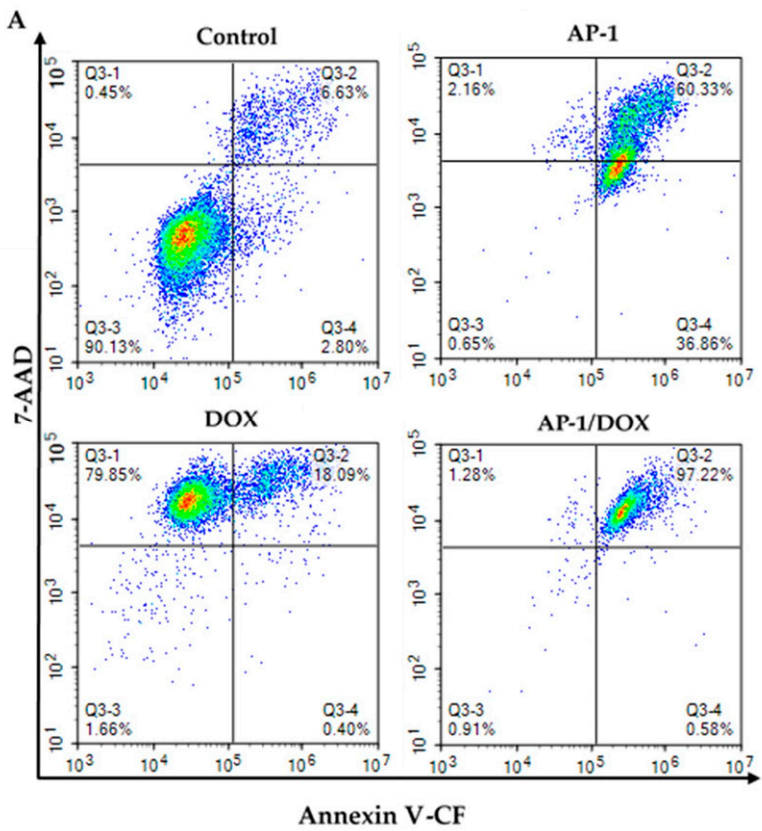

B

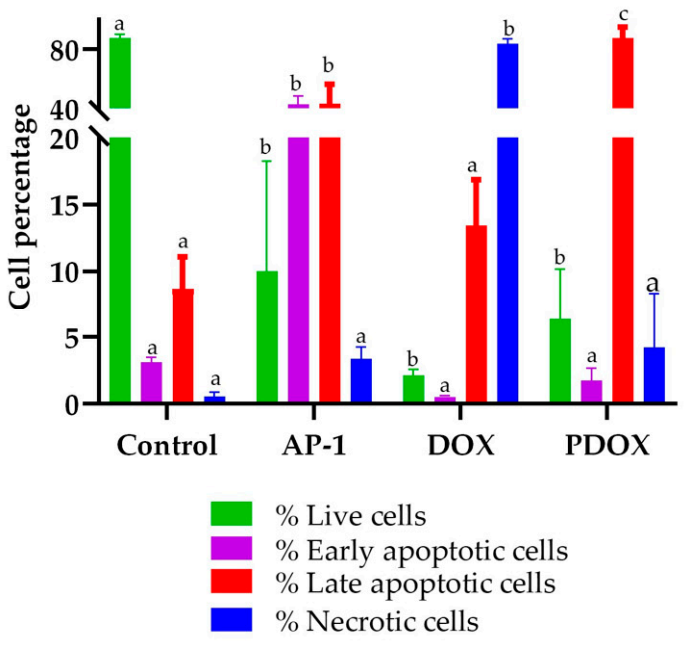

Figure 6. (A) Flow cytometric assessment of apoptotic profiles of the MCF7 breast cancer cell line and the images are representative of three separate experiments, (B) Cell percentage analysis in different treatment groups in quadruplicates. The AP-1 $\left(100 \mu \mathrm{g} \mathrm{mL}^{-1}\right)$, DOX $\left(0.29 \mu \mathrm{g} \mathrm{mL}^{-1}\right)$ and their most synergistic combination (at half-dose; $50 \mu \mathrm{g} \mathrm{mL}{ }^{-1} \mathrm{AP}-1$ $+0.15 \mu \mathrm{g} \mathrm{mL}^{-1} \mathrm{DOX}$ ) with the vehicle control were implemented using antibodies against Annexin-V CF-Blue and the reporter 7AAD after $24 \mathrm{~h}$ of treatment. Superscript letters indicate statistical significance derived from two-way ANOVA and Tukey's multiple comparisons within the same cell group (bar colour) where different letters are statistically significant with $p<0.0001(n=4)$. Raw data are available in Supplementary Table S3. 


\subsection{Apoptotic Proteome Profiler Array Analysis}

\subsubsection{Effects of AP-1 and DOX on Apoptotic Proteins of the MCF7 Cells}

The proteome profiler ${ }^{\mathrm{TM}}$ human apoptosis array kit was used to study the effect of AP1 and DOX treatments on 35 apoptotic proteins of the MCF7 breast adenocarcinoma cells. The differential expression of the apoptotic proteins after mono and combined treatments are shown in Figure 7A,B. Figure 7A shows the mono treatments and combination in distant clusters from the control using hierarchical clustering on the top of the heatmap with the help of Euclidean distance measure and Ward clustering algorithm. Furthermore, both unsupervised principal component analysis (PCA) and supervised partial least square discriminant analysis (PLS-Da) indicated the distinct clustering of different treatments and the synergistic combination away from the control based on the profile of apoptotic proteins (Figure S5A,B). The corresponding proteins for the array coordinates are listed in Table S4. Livin, HO-1/HMOX1/HSP32, and Bcl-X, respectively, are identified as the most discriminatory apoptotic proteins among the treatments by variable importance projection (VIP) scores in the constructed PLS-Da model (Figure S5C, red rectangles on the control array Figure 7B). However, PLS-Da coefficient scores outlined the significance of claspin, livin and catalase, respectively, in the classification model (Figure S5D, blue rectangles on the control array Figure 7B). Both scores identified livin as a characteristic protein among different MCF7 cell lysates in this study.

The differentially expressed proteins were selected if their $p$-value was $\leq 0.05$ with an absolute fold change of 1.3 in the pairwise comparisons (Figure 7C,D and Table S5). The top two downregulated or upregulated proteins in the AP- 1 and DOX treatment groups (based on fold change compared to the vehicle control) were marked on the arrays by blue and red rectangles, respectively (Figure 7B). These dysregulated proteins are also indicated in the volcano plot Figure $7 \mathrm{C}, \mathrm{D}$, where upregulated and downregulated proteins are located on the right and left parts away from the central volcano plot axis $(0,0)$, respectively. Thus, more significant proteins are positioned away from the centre and the bottom part of the volcano plot.

Bcl- $x$, claspin, pro-caspase-3, survivin, and cIAP-2 were significantly downregulated in the MCF7 cells after mono treatment with AP-1 and DOX. Bcl-x and claspin were the top-two downregulated proteins (Figure 7A-D and Table S5). Bcl-x is a dominant apoptosis regulator in mammalian cells with the long-form (Bcl-xL) responsible for anti-apoptotic effects, and the short isoforms (Bcl-xS and Bcl-xb) promote apoptosis. Bcl-x belongs to the Bcl-2 (B-cell lymphoma 2) family, which can exert either anti-apoptotic or pro-apoptotic effects and is recognised among pro-survival Bcl-2 subfamily members alongside Bcl-w and Mcl-1 [94]. The Bcl-2 subfamily of proteins can promote cell survival by inhibiting the activation of the caspases [94]. Interestingly, the downregulated Bcl-x expression was previously reported as a possible indicator of chemoresistance in myeloma [95] and an inhibitor of Fas-mediated apoptosis in the MCF7 cells [96]. The Bcl-2 level was significantly downregulated in the MCF7 cells after treatment with DOX. Parallel observations were made previously where DOX and etoposide conferred antiproliferative effect via the downregulation of Bcl-2 expression in the MCF7 cells [97]. Induction of autophagy in the MCF7 cells was also observed earlier by Bcl-2 silencing via siRNA [98]. Additionally, Bad (Bcl-2 associated agonist of cell death) was downregulated by DOX. Bad is an antiapoptotic or pro-apoptotic member of the Bcl-2 family depending on its serine 75, 99 and 118 phosphorylation state [99].

Claspin is an essential component for the ATR-Chk1-dependant activation of the DNA replication in human cells $[100,101]$. Recently, claspin overexpression was reported to protect the HCT116 cells from replication stress in a checkpoint independent manner [102]. Both AP-1 and DOX significantly suppressed the expressions of claspin and survivin. Claspin is usually overexpressed in almost all malignancies with proliferating and anti-apoptotic activity [103]. Taken together, the downregulated claspin and survivin contributed to the DOX and AP-1 -mediated apoptosis in the MCF7 cells. Previously, 
DOX was reported to induce cell death in the MCF7 and the MDMB231 breast cancer cells regardless of the expression level of survivin [104].
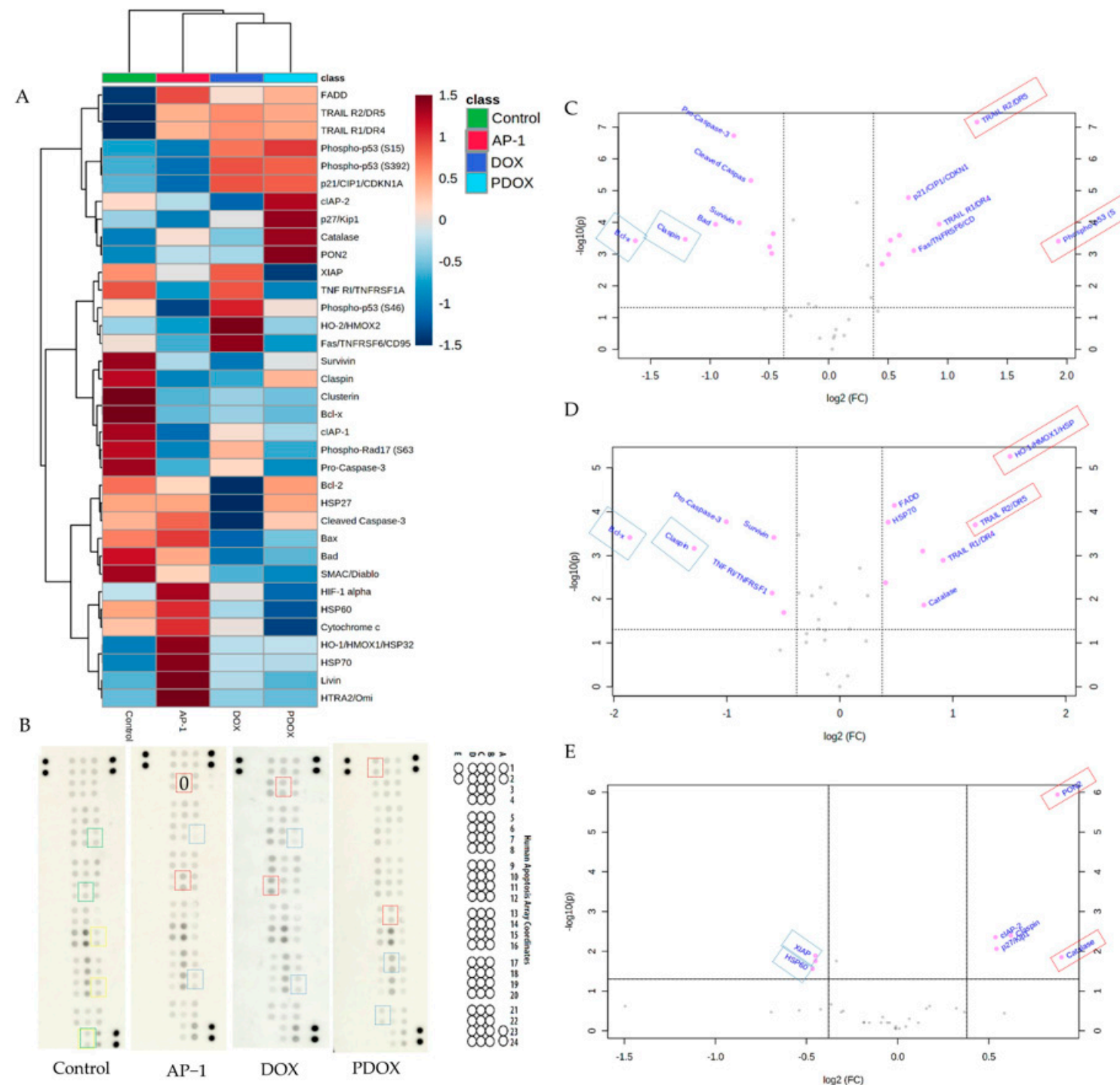

Figure 7. Differently expressed apoptotic proteins in the MCF7 cell lysates after treatment with AP-1, DOX, and the synergistic combination (PDOX). (A) Mean apoptotic proteins expression heatmap of the proteome arrays processed data after treatment of MCF7 cells with the vehicle (0.5\% DMSO), $0.29 \mu \mathrm{g} \mathrm{mL}{ }^{-1} \mathrm{DOX}, 100 \mu \mathrm{g} \mathrm{mL} \mathrm{m}^{-1} \mathrm{AP}-1$ and their synergistic combination with hierarchical clustering of the groups using the Euclidean distance measure and Ward clustering algorithm. (B) The MCF7 lysates were analysed by Proteome Profiler ${ }^{\mathrm{TM}}$ human apoptotic arrays after $24 \mathrm{~h}$ of treatment. The significant features are marked with blue and red rectangles (other than the vehicle control), indicating the downregulation and upregulation of proteins, respectively. The yellow and green rectangles on the control array indicate the significant proteins identified by coefficient and VIP scores of the PLS-DA model, respectively. Protein coordinates are listed in Table S4. (C) The significantly dysregulated apoptotic proteins after DOX treatment as selected by volcano plot compared to the control with the fold change (FC) threshold (x) 1.3 and $t$-test threshold (y) 0.05. (D) The significantly dysregulated apoptotic proteins after AP-1 treatment as selected by volcano plot compared to the vehicle control with the FC threshold (x) 1.3 and $t$-test threshold (y) 0.05. (E) The significantly dysregulated apoptotic proteins after treatment with the synergetic combination $\left(100 \mu \mathrm{g} \mathrm{mL}{ }^{-1}\right.$ AP-1 and $0.29 \mu \mathrm{g} \mathrm{mL}^{-1}$ DOX) as selected by volcano plot compared to the vehicle control with the FC threshold (x) 1.3 and $t$-test threshold (y) 0.05 . The fold changes and $p$ values are log-transformed, and the further the FC values are from the $(0,0)$, the more significant the feature is. 
The expressions of anti-apoptotic proteins such as Bcl-2 and survivin were also correlated to the HER-2 expression in the MCF7 cells [105]. The HER-2 oncogene is considered a relevant biomarker and an essential target for approximately $30 \%$ of breast cancer patients [106].

The inhibitors of apoptosis (IAPs) are overexpressed in breast cancer cell lines (MCF7 and MDA-MB-231) [107-109] and breast cancer patients [110,111]. AP-1 and DOX significantly downregulated the expressions of two IAPs, namely, the cIAP-1 and cIAP-2 (Figure 7A).

The caspase-3 deficiency in the MCF7 was reported to contribute to its chemotherapeutic resistance, where its expression in the MCF7 cells increased the DOX efficacy [112]. Discrepant detection of caspase 3 in the MCF7 cells [113-117] concerns amid CASP-3 partial deletion and the lack of caspase-3 expression reported in the MCF7 cells [118,119]. Such contradictory findings may be partially explained by using inappropriate antibodies that cross-react with other caspase-3-unrelated proteins or cross-reactivity on fluorogenic substrates, especially with caspase-7 and cathepsin B $[119,120]$. In the current study, procaspase-3 expression was significantly downregulated in the MCF7 cell upon AP-1 and DOX treatments. However, the cleaved caspase- 3 (the active form of caspase- 3 responsible for apoptotic signal) was found to be downregulated in the DOX treatment group compared to the vehicle control (Figure 7A,B), which might be inconsistent with the downregulation of $\mathrm{Bcl}-2$. The activated caspases are responsible for the cleavage (downregulation) of Bcl-2 [121].

Clusterin is an apoptosis inhibitor that exerts its effect via its interaction with the activated Bax [122] and is considered a key component for chemoresistance [123], where its inhibition sensitised the MCF7 and MDA-MB-231 cells to chemotherapy [124]. Clusterin was significantly suppressed by Dox treatment of the MCF7 cell in the current study.

The loss of p53 pro-apoptotic functions was reported to be associated with the resistance of MCF7 cells to TNF-induced cytotoxicity [125-127]. However, the apoptotic activity of AP-1 may not p53-related as the Phospho-p53 (S392) was significantly suppressed $(p<0.05)$, and other Phospho-p53 including S15 and S46 were also downregulated, although not statistically significant compared to the vehicle control $(p>0.05)$. Previously, upregulation of p-53 was reported in the MCF7 cells after treatment with Chinese [128] and Turkish propolis [129]. Our recent study showed the discriminatory metabolites of AP-1 vs. Chinese and Brazilian samples, indicating a greater antiproliferative effect of AP-1 against the MCF7 and MDA-M-B231 cells [49]. The discrepancies in the underlying cytotoxic mechanisms may be correlated to different key metabolites in the propolis samples, accounting for their differential effects on p53 expression. In contrast, the apoptotic effect of DOX in the MCF7 cells was mediated by increased phosphorylated p-53 proteins, including phospho-p53 (S15) and phospho-p53 (S15). These findings are in line with the previous reports indicating the involvement of the $\mathrm{p}-53$ signal transduction pathway in DOX-induced apoptosis [130-133].

The other apoptotic proteins- Fas and p21 were significantly upregulated in the DOX treatment group, in agreement with previous studies [133-136]. Furthermore, the MCF7 cell death was mediated by upregulation of TRAIL (TNF-related apoptosis-inducing ligand) R1/DR4 and TRAIL R2/DR5 expression by both AP-1 and DOX. In the current study, the (TRAIL)-mediated apoptosis is confirmed for DOX and AP-1, although the TNF RI/TNFRSF1A (Tumour necrosis factor receptor superfamily member 1A) was downregulated in the latter. The TRAIL-mediated apoptosis was also reported previously for DOX [137-139]. The TNFRSF1A is a member of the TNF receptor superfamily and one of the central receptors for TNF- $\alpha$, and its gene knockout was demonstrated to induce apoptosis in triple-negative breast cancer cells [140].

Heme oxygenases, including HMOX-1 and HMOX-2, were upregulated after DOX treatment, while HMOX1 only was upregulated in the AP-1 treatment group. The ROS generation from the redox cycling of DOX was found to be responsible for its cytotoxicity. However, the Nrf2 signalling pathway activation was reported as a chemoprotective mechanism against DOX and liable for its inclined resistance [141,142]. The DOX and AP-1 
treatments also upregulated livin in the MCF7 cells, an IAP, and its surge may account for drug resistance and tumour progression [143]. HIF-1 $\alpha$ and HSP-70 have been overexpressed as a defence mechanism against propolis-induced cytotoxicity. These proteins have been reported to mediate metastasis and inhibit cancer cell apoptosis [144-147].

Heat shock proteins, including four HSP70s (Hsp70-1, Hsc70, Grp75, and Grp78), were the most abundant in MCF7 and associated with estrogen receptor alpha (ER $\alpha)$ followed by HSP90 and HSP110 and thereby effectively able to regulate the ER-mediated cell proliferation $[147,148]$. Catalase is a critical antioxidant enzyme that metabolises $\mathrm{H}_{2} \mathrm{O}_{2}$ and reactive nitrogen species, and in tumours, its expression and localization are significantly dysregulated [149]. It was reported to be overexpressed in resistant cancer cells, and its downregulation can lead to enhanced cytotoxicity of these cells [150]. However, the upregulated catalase expression suppressed the chemically induced colon cancer in mice model [151] and reduced breast cancer invasiveness and metastasis in the transgenic mice model expressing mitochondrial catalase [152]. Several reports also portrayed the decreased catalase expression in cancer and other diseases [153-165]. In an earlier study, the proliferation and migration of the MCF7 cells were reduced via catalase overexpression with increased sensitivity to chemotherapy, including etoposide and paclitaxel [166].

The apoptotic effect of AP- 1 was also regulated via inclined HTRA2/Omi and FADD ( $\mathrm{FC}=1.66$, and 1.4, respectively) together with the TRAIL-mediated apoptosis. FADD is involved in the Fas signal transduction and reported for its Fas-induced apoptosis in the MCF7 cells [167], and its JNK-mediated phosphorylation was demonstrated to play a critical role in the regulation of cell cycle, cellular growth and metastasis and was not dependent on the ER status of breast cancer [168]. Additionally, the activation of caspasedependent mitochondrial pathways was reported earlier via the overexpression of the pro-apoptotic HTRA2/Omi [169-171].

Altogether, the significant overexpression of catalase, HTRA2/Omi, FADD with TRAIL-mediated apoptosis with 2.3, and 1.89 FC for DR5 and DR4, respectively, provide an insight into the cytotoxic mechanisms of AP-1 against the MCF7 cells.

2.5.2. Effects of the Most Synergistic AP-1 and DOX Combination on Apoptotic Proteins of the MCF7 Cells

The most synergistic combination $\left(100 \mu \mathrm{g} \mathrm{mL}^{-1} \mathrm{AP}-1\right.$ and $0.29 \mu \mathrm{g} \mathrm{mL}^{-1}$ DOX) significantly downregulated the expression of XIAP, HSP60, Cytochrome c, and HIF-1 $\alpha$ (0.71-0.77 FC), and upregulated cIAP-2, p27/Kip1, claspin, PON2, and catalase (1.5-2.04 FC) as shown in Figure 7 and Table S5. Overall, the synergistic combination mediated the apoptosis of the MCF7 cells by downregulating anti-apoptotic proteins in addition to the paradox effect of antioxidant paraoxonase 2 (PON2) and catalase.

The overexpression of XIAP was previously found to be associated with breast cancer survival and chemoresistance [97,172]. Its downregulation might lead to enhanced MCF7 sensitivity. The HSP-60 is a mitochondrial protein with pro-survival and anti-apoptotic effects upon binding with survivin in the mitochondria where the survivin is stabilised, and cancer cell survival is achieved [173,174]. The downregulation of HSP60 observed in our study after treatment with the AP-1 and DOX combination might facilitate caspasedependent apoptosis via destabilising survivin, inducing mitochondrial dysfunction and enhancing p53 function [173,174].

The paradoxical effects of PON2 have been reported earlier, as its overexpression was suggested to prevent the formation of ovarian tumours in the mouse xenograft model of ovarian cancer [175]. The cytotoxic effect against ovarian cancer was demonstrated to be mediated through the increased PON2 expression, which downregulated the expression of insulin-like growth factor-1 (IGF-1) by its antioxidant-related decline in cholesterol production. As a result, cholesterol was not available as a substrate for estrogen production in ovarian cancer cells. The PON2-dependent downregulated expression of IGF-1 and suppressed estrogen production in the ovaries may also be beneficial for breast cancer treatment [176-179]. In addition, similar to the inhibition of ovarian tumours, the PON2mediated inhibition of breast cancer can be speculated as both cancers share common 
etiology with $B R C A 1$ and $B R C A 2$ mutations and elevated estrogen levels [180-182]. The second significantly upregulated protein in the MCF7 cells after the treatment with the synergistic combination was catalase, and its antiapoptotic effect against the MCF7 cells was discussed in Section 2.5.1.

The increased expression of cytochrome c has been correlated with the apoptotic activity of cells and cells undergoing apoptosis in vivo, where cytochrome $\mathrm{c}$ was found to be released to their cytosol [183]. Notably, Bcl-xL was reported to block cytochrome c release from the mitochondria into the cytosol preventing its apoptotic effect [184] and the tyrosine residue (Tyr48) phosphorylation by cytochrome c-phosphorylating kinase impairs Apaf1-mediated caspase activation, where cytochrome $c$ acts as an anti-apoptotic switch [185]. However, as observed in the flow cytometry data, the synergistic combination at its halfdose resulted in $87.59 \pm 7.44 \%$ of the MCF7 cells in the late apoptotic stage after $24 \mathrm{~h}$. This might indicate that the release of cytochrome $\mathrm{c}$ and subsequent activation of caspase cascade leading to early apoptosis took place earlier than $24 \mathrm{~h}$, and hence, cytochrome c was not found to upregulated in the Apoptosis proteome profiler array analysis.

Cyclin-dependent kinase inhibitor 1B (p27/Kip1) is a tumour suppressor and cell cycle inhibitor protein that regulates the cell cycle progression at the G1 phase via hindered activation of cyclin E-CDK2 or cyclin D-CDK4 complexes [186,187]. Furthermore, declined p27 in breast cancer cells was correlated with oncogenic kinase Src activation, which accelerates $\mathrm{p} 27$ proteolysis [188]. Therefore, the significant $\mathrm{p} 27 / \mathrm{Kip} 1$ overexpression by the synergistic combination $\left(\mathrm{FC}=1.5, p\right.$-value $=1.031 \times 10^{-3}$ and $\left.\mathrm{FDR}=9.018 \times 10^{-3}\right)$ in the MCF7 cells compared to the mono treatments may contribute to the observed synergistic effects.

These findings encourage the implementation of the synergistic combination of AP-1 and DOX in either estrogen or progesterone receptor-negative breast cancers [188] and $B R C A 1 / 2$ mutated breast cancers [189] with low levels of p27 expression.

Altogether, the enhanced apoptotic activity found in the flow cytometry analyses of the synergistic combination compared to the mono treatments against the MCF7 cells may be associated with upregulated expressions of pro-apoptotic p27, PON2 and catalase and downregulation of anti-apoptotic XIAP, HSP60 and HIF- $1 \alpha$. Furthermore, the enhanced antioxidant proteins in the MCF7 cells after treatment with the synergistic combination may be associated with the shift of the DOX-induced necrosis into programmed cell death observed in the flow cytometry analysis (Figure 6).

2.6. Bottom-Up Label-Free Quantification Proteomic Study of the MCF7 Cells after Treatment with $A P-1, D O X$ and Their Synergistic Combination

A discovery study on the MCF7 cells treated with AP-1, DOX and their synergistic combination was performed using label-free LC-MS/MS proteomics. The differently expressed proteins in the MCF7 cells belonging to the three treatment groups were analysed in pairwise comparison to the vehicle control or the mono treatments in case of the synergistic combination. The peptide counts, unique peptide counts, $m / z$ of the identified 1687 proteins, the confidence scores and the statistics, and the fold change (FC) calculations are listed in different worksheets of Supplementary File 2, together with quality control metrics and overlapped proteins among experimental groups shown in Figure 8. Peptides with an absolute mass error of $20 \mathrm{ppm}$ were omitted from the study based on the mass error distribution of the identified peptides (Figure $8 \mathrm{~A}$ ). The differentially expressed proteins in the synergistic combination-treated cells were selected based on the ANOVA test, $p$ and q-values of $\leq 0.01$ ( $\mathrm{q}$-values are the adjusted $p$-values based on the optimised false discovery rate (FDR) approach) with an absolute FC $\geq 1.7$. Six upregulated, and fifteen downregulated proteins were identified in the synergistic combination group compared to the averaged protein expression in mono treatment groups (Table 2). These 21 dysregulated proteins display the proteome-level variance acquired by combining AP-1 and DOX. Therefore, it may reflect the possible underlying synergistic mechanisms of action against the MCF7 breast adenocarcinoma cells. 
When the set of dysregulated proteins of the synergistic combination-treated MCF7 cells was considered, g:Profiler identified a subset of proteins-encoding genes such as MDC1, RIF1, and BRCA1 involved in both Nonhomologous End-Joining (NHEJ), and DNA ionising radiation (IR)-double-strand breaks (DSBs) and cellular response via ataxiatelangiectasia mutated (ATM) (Figure 9A and Table 3). The NHEJ pathway was also overrepresented in the Reactome analysis and confirmed with DSB-repair via STING analysis showing a network of interactions involving additional genes such as $\mathrm{CHD} 3$, FAM83H and LAMA4 (Figure 9B). Genes such as MDC1, BRCA1, CHD3, and COX6B1 were involved in the transcriptional regulation by TP53 as significantly identified by Reactome (Table 3 and Table S6) and IMPaLA (Table S7). Other pathways were spotted by Reactome with the $p$-value $<0.05$, but high FDR values $(0.1-0.16)$ such as cell cycle checkpoints (MDC1, MAST1 and BRCA1), $\mathrm{G}_{2}$ /M DNA damage checkpoint (MDC1 and BRCA1) and nonsense-mediated decay (UPF2 and RPL11; both were also linked in STRING network).

A

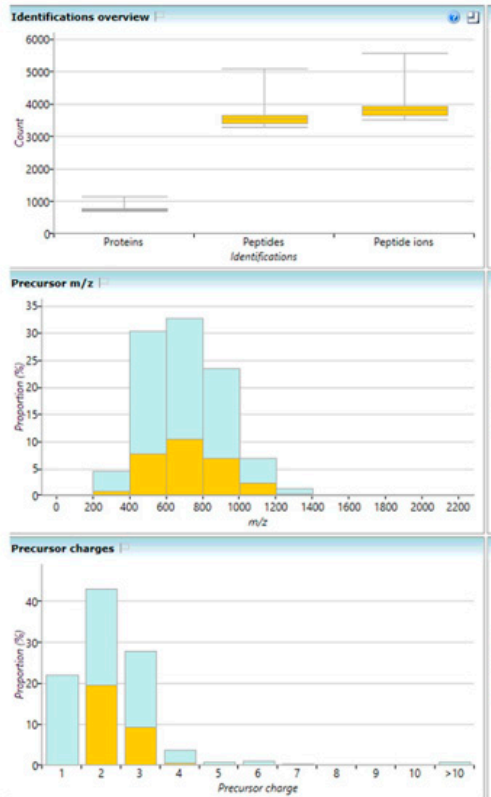

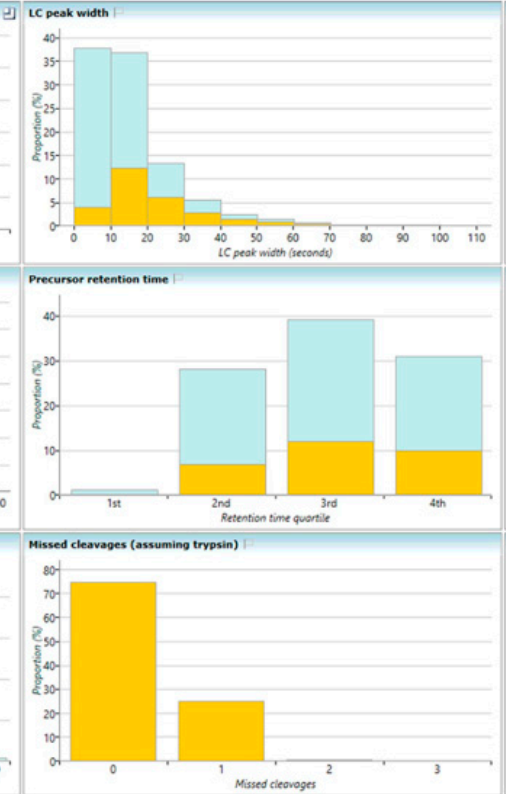

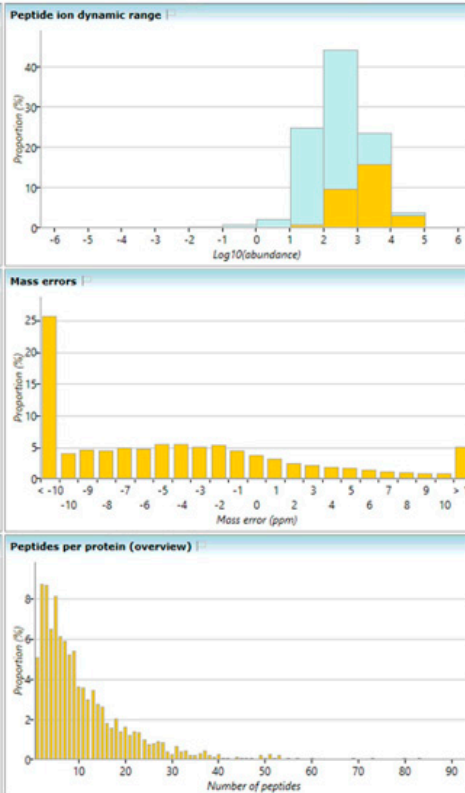

B

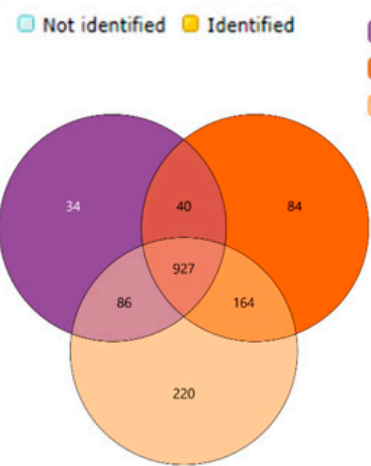

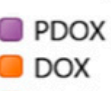

DOX
AP-1

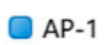

Control
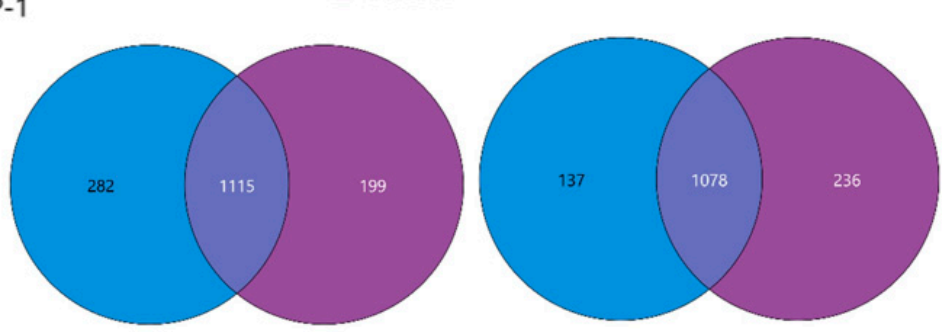

Figure 8. (A) Overview of quality control metrics of LC-MS/MS shotgun proteomic study of the MCF7 cells after treatment with AP-1, DOX and their synergistic combination (PDOX). (B) Venn diagrams of the overlapped identified proteins in the differently treated groups. 
Table 2. Differentially expressed proteins in the MCF7 cells treated with the synergistic AP-1 and DOX combination.

\begin{tabular}{|c|c|c|c|}
\hline Uniprot Accession & Gene & Fold Change & Description \\
\hline \multicolumn{4}{|l|}{ Upregulated Proteins } \\
\hline H0YMP8 & ATP8B4 & 15.05 & Phospholipid-transporting ATPase \\
\hline A0A0A0MQS9;Q16363 & $L A M A 4$ & 4.60 & Laminin subunit alpha-4 \\
\hline Q9HAU5 & UPF2 & 3.22 & Regulator of nonsense transcripts 2 \\
\hline Q9Y216 & SEC23A & 2.53 & Myotubularin-related protein 7 \\
\hline P38398 & $B R C A 1$ & 1.77 & Breast cancer type 1 susceptibility protein \\
\hline E9PDF1 & SH3TC2 & 1.74 & SH3 domain and tetratricopeptide repeats 2 \\
\hline \multicolumn{4}{|l|}{ Downregulated Proteins } \\
\hline Q9HCY8 & S100A14 & 18.96 & Protein S100-A14 \\
\hline H3BUX2 & CYB5B & 5.09 & Cytochrome b5 type B \\
\hline Q8N5U6 & RNF10 & 3.73 & RING finger protein 10 \\
\hline H7C2B5 & RIF1 & 3.58 & Telomere-associated protein RIF1 \\
\hline Q8N9V7 & TOPAZ1 & 2.86 & Protein TOPAZ1 \\
\hline Q14676 & MDC1 & 2.63 & Mediator of DNA damage checkpoint protein 1 \\
\hline Q12873 & CHD3 & 2.59 & Chromodomain-helicase-DNA-binding protein 3 \\
\hline Q9NSB2 & KRT84 & 2.49 & Keratin_type II cuticular $\mathrm{Hb} 4$ \\
\hline A0A087WWY9; Q8TB24 & RIN3 & 2.35 & Ras and Rab interactor 3 \\
\hline P62913 & RPL11 & 2.32 & 60S ribosomal protein L11 \\
\hline D6RCP5 & ARHGAP24 & 2.08 & Rho GTPase-activating protein 24 \\
\hline Q9NYL9 & TMOD3 & 1.88 & Tropomodulin-3 \\
\hline Q9Y2H9 & MAST1 & 1.83 & $\begin{array}{l}\text { Microtubule-associated } \\
\text { serine/threonine-protein kinase } 1\end{array}$ \\
\hline Q6ZRV2 & FAM83H & 1.82 & Protein FAM83H \\
\hline $\mathrm{P} 14854$ & COX6B1 & 1.77 & Cytochrome c oxidase subunit $6 \mathrm{~B} 1$ \\
\hline
\end{tabular}

AP-1 = Australian propolis extract; DOX = Doxorubicin

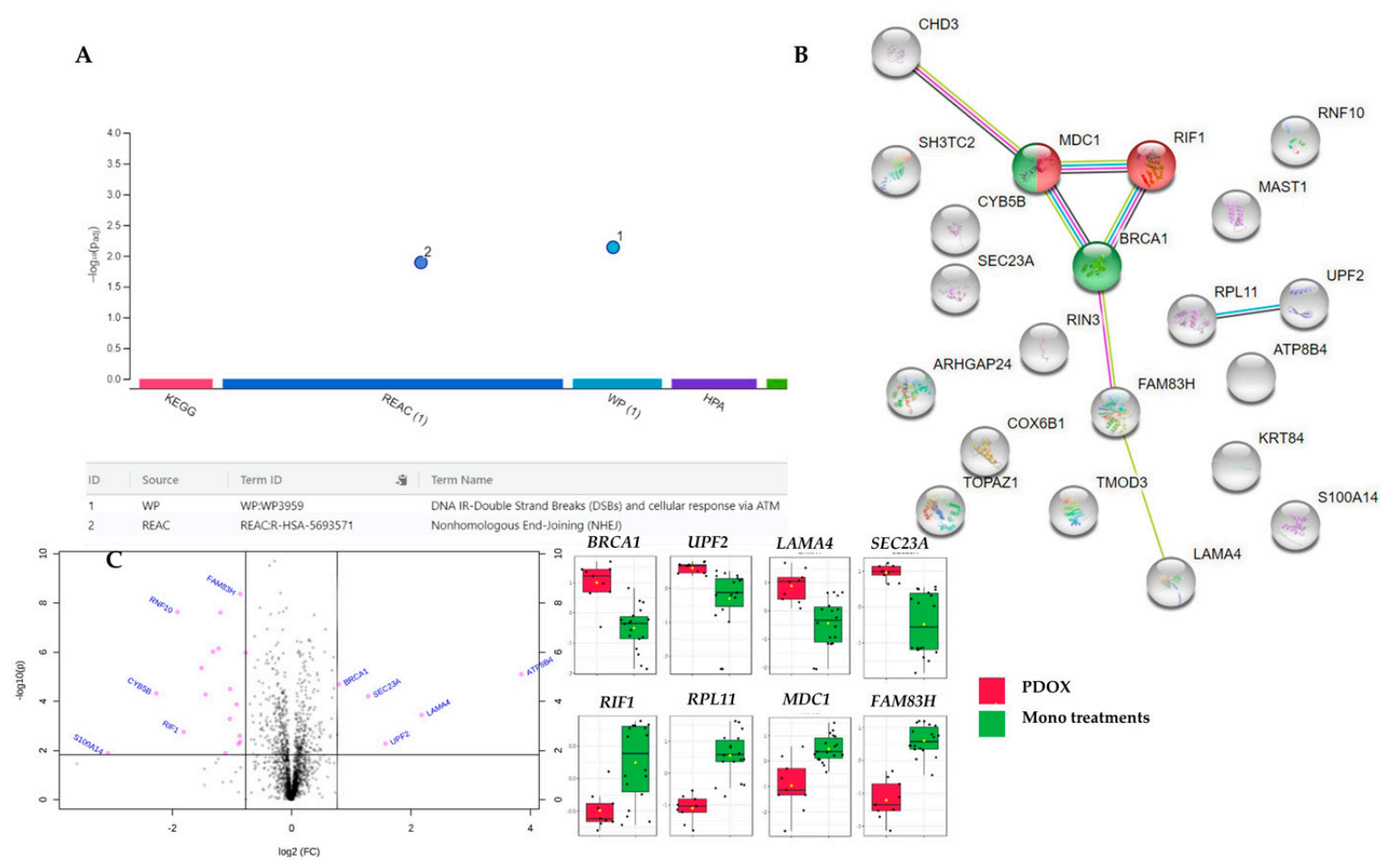

Figure 9. (A) Enriched pathways using g:Profiler, (B) STRING network of the differentially expressed proteins in the synergistic combination-treated MCF7 cells and (C) Volcano plot of $0.015 p$-value and absolute 1.7 FC threshold among identified proteins in the synergistic combination-treated cells with selected proteins expression summary (PDOX = synergistic combination of AP-1 and DOX). BRCA1-A complex and BRCT domain associated proteins in red and green, respectively, in STRING network. WP; Wikipathways, REAC; Reactome. 
Table 3. Significantly overrepresented pathways identified via Reactome, STRING and g:Profiler using differentially expressed protein in the MCF7 cells treated with the synergistic AP-1 and DOX combination.

\begin{tabular}{|c|c|c|c|c|}
\hline Platform. & Process/Pathway & $p$-Value & FDR & Present Entities \\
\hline \multirow[t]{6}{*}{ Reactome } & $\begin{array}{l}\text { TP53 Regulates Transcription of DNA } \\
\text { Repair Genes }\end{array}$ & $1.78 \times 10^{-8}$ & $3.29 \times 10^{-06}$ & $M D C 1 ; B R C A 1$ \\
\hline & Transcriptional Regulation by TP53 & $2.72 \times 10^{-06}$ & $2.50 \times 10^{-04}$ & $M D C 1 ; B R C A 1 ; C H D 3 ; C O X 6 B 1$ \\
\hline & NHEJ & $1.84 \times 10^{-04}$ & $1.12 \times 10^{-02}$ & $M D C 1, R I F 1, B R C A 1$ \\
\hline & $\mathrm{G}_{2} / \mathrm{M}$ DNA damage checkpoint & $1.07 \times 10^{-02}$ & $1.07 \times 10^{-01}$ & $M D C 1 ; B R C A 1$ \\
\hline & Cell Cycle Checkpoints & $1.64 \times 10^{-02}$ & $1.47 \times 10^{-01}$ & MDC1; MAST1; BRCA1 \\
\hline & Nonsense-Mediated Decay (NMD) & $2.38 \times 10^{-02}$ & $1.67 \times 10^{-01}$ & UPF2; RPL11 \\
\hline \multirow[t]{2}{*}{ STRING } & DSBs repair via NHEJ & NA & 0.047 & $M D C 1, R I F 1, B R C A 1$ \\
\hline & $\begin{array}{l}\text { BRCT, breast cancer } \\
\text { carboxy-terminal domain }\end{array}$ & NA & 0.022 & $M D C 1, B R C A 1$ \\
\hline \multirow[t]{2}{*}{ g:Profiler } & NHEJ & $1.30 \times 10^{-2}$ & NA & $M D C 1, R I F 1, B R C A 1$ \\
\hline & $\begin{array}{l}\text { DNA IR-DSBs and cellular } \\
\text { response via ATM }\end{array}$ & $7.00 \times 10^{-3}$ & NA & $M D C 1, R I F 1, B R C A 1$ \\
\hline
\end{tabular}

DSB; double-strand breaks, NHEJ; Nonhomologous End-Joining, underlined values are $>0.05$. Red and blue are up- and downregulated entities, respectively.

The breast cancer type 1 susceptibility protein encoded by BRCA1, a tumour suppressor gene, was significantly upregulated with $1.77 \mathrm{FC}$ in the synergistic combination group compared to averaged mono treatments (Figure 9C). BRCA1 mutations are responsible for $40 \%$ and $80 \%$ of inherited ovarian and breast cancers, respectively. Downregulated or undetectable levels of $B R C A 1$ expression were reported in most high-grade ductal breast cancers [190] and MCF7 cells [191]. The downregulation of BRCA1 has been shown to contribute to sporadic and inherited breast cancer progression [192] due to the declined repairs of DNA damage and double-strand breaks with increased gross chromosomal rearrangement and mutations leading to breast cancer progression [193]. BRCA1 is associated with RIF1 and MDC1 in NHEJ and with MDC1 only in TP53 transcriptional regulation of DNA repair genes (Figure S6) and DNA double-strand breaks-repairs pathways as identified in different pathway enrichment platforms (Table 3). NHEJ pathway is initiated as a response to DNA-damaging agents causing DNA double-strand breaks with subsequent ATM activation and $M D C 1$ recruitment for the formation of nuclear foci with the recruitment of DNA damage checkpoints and repairs [194-198]. Ultimately, BRCA1 and TP53BP1 are recruited which is crucial for ATM-mediated CHECK2 activation and DNA repair $[199,200]$. RIF1 and PAX1IP were reported to prevent resection of DNA doublestrand break needed for homologous recombination repair via replacing BRCA1:BARD1 and associated proteins in the DNA double-strand breaks [201,202]. Altogether, AP-1 significantly synergised doxorubicin against the metastatic MCF7 breast adenocarcinoma cells via TP53/ATM-mediated homologous recombination DNA double-strand break repair mediated through upregulation of BRCA1 and downregulation of RIF1.

The upregulation of UPF2 has been linked with impeded proliferation, G2/M cell cycle arrest, and migration defects in the knocked down ARA (Adriamycin; Doxorubicin Resistance Associated long non-coding RNA) in doxorubicin-resistant MCF7 cells [203]. Moreover, UPF2 was associated with nonsense-mediated decay (NMD), which is a quality control mediated degradation of faulty transcripts $[204,205]$ via the exon-junction complex (EJC) [206]. Interestingly, patients with brain metastatic breast cancer showed significant downregulation of the regulator of nonsense transcripts 2 protein (UPF2-encoded) in the brain metastases compared to the primary breast tumour [207]. Our study observed that the regulator of nonsense transcripts 2 was overexpressed in the synergistic combinationtreated MCF7 cells. Thus, the UPF2 overexpression by the synergistic AP-1 and DOX combination might be advantageous to overcome doxorubicin resistance in breast cancer cells with potential suppression of its metastasis. 
Protein S100-A14, a member of EF-hand calcium-binding proteins, was the most downregulated protein in the synergistic combination-treated MCF7 cells (Table 2, Figure 9C). HER 2 is overexpressed in $20-25 \%$ of breast cancer, and it stimulates tumorigenesis through signalling molecules such as PI3K/AKT and MAPK/ERK [208]. S100-A14 protein is a modulator of HER2 signalling by directly binding to HER2 protein [208]. Previously, reduced HER2-stimulated cell proliferation was observed after silencing the S100A14 in MCF7, BT474, and SK-BR3 breast cancer cells [208]. In addition, co-overexpression of S100A14 with S100A16 promoted the invasiveness of the MCF7 and SK-BR-3 breast adenocarcinoma cells [209]. Collectively, in our study, the synergistic combination of AP-1 and DOX reduced the expression of S100-A14, which in turn may have reduced the HER-2 stimulated proliferation and invasiveness of the MCF7 cells.

\section{Conclusions and Future Directions}

Strong synergistic interactions were observed between AP-1 and DOX against MCF7 cells using different synergy quantitation models with a promising CSS. Interestingly, CSS and S scores were able to capture the combination efficacy and synergy, respectively, for both CI-model data and its collective combination when reanalysed in DrugComb, unlike other synergy metrics (ZIP, LOEWE, BLISS, and HSA). However, ZIP, LOEWE, BLISS, and HSA synergy metrics were strongly correlated with CI values at different inhibitory concentrations.

Our results demonstrated that ROS depletion is associated with the MCF7 cell death after mono or combination treatment in a dose-dependent manner. Furthermore, the most synergistic combination led to a significant decline in ROS production in the MCF7 cells compared to monotherapy with DOX. However, the statistically significant ROS decline upon DOX treatment in the MCF7 cells in our study was not in agreement with the established DOX-induced ROS in cancers and normal tissue in the literature. Therefore, further studies using different doses of DOX with different treatment time points with the help of multiple ROS quantifying protocols and molecular studies are warranted to investigate any biphasic dose- and/or time-dependent DOX-mediated ROS production. In particular, the differential effects of antioxidants on DOX-mediated apoptosis and caspase 3 activity in normal vs. tumour cells reported in the literature support the use of AP-1 in combination with DOX. The observed ROS decline by DOX and/or AP-1 in the MCF7 cells along with the displayed apoptosis in our study suggests the involvement of other mechanisms controlling MCF7 cell death, highlighting the need for further mechanistic studies particularly amid the paradoxical and complex role of ROS in cancer.

AP-1 potentiated the anticancer activity of DOX by promoting apoptosis and facilitated a necrosis reversal to programmed cell death, which may be advantageous to decline DOX-related side effects. The observed necrotic to an apoptotic shift of DOX by the synergistic combination may be attributed to the antioxidant profile of AP-1 and the resultant antioxidant-related apoptotic pathways in the MCF7 cells. Nonetheless, further studies will be needed to completely characterise the underlying mechanisms of the observed necrosis to apoptosis shift by implementing a number of necrotic and apoptotic markers.

The enhanced apoptosis may be associated with upregulated expressions of proapoptotic p27, PON2, and catalase alongside downregulated anti-apoptotic XIAP, HSP60, and HIF- $1 \alpha$ proteins. The AP- 1 mediated overexpression of antioxidant proteins such as PON2 and catalase in the combination treatment group may be associated with the increased apoptosis of MCF7 cells and impeded oxidative stress-related side effects of DOX. In addition, the upregulated HTRA2/Omi, FADD, DR5, and DR4 contributed to the cytotoxic mechanisms of AP-1 against the MCF7 cells.

Label-free quantification-driven proteomics highlighted the top 21 differentially expressed proteins of MCF7 cells in the combination treatment group among the total identified 1687 proteins. AP-1 significantly synergised doxorubicin against the metastatic MCF7 breast adenocarcinoma cells via TP53/ATM-mediated homologous recombination for the DNA DSBs repair through BRCA1 upregulation and RIF1 downregulation. Undermined 
HER-2 stimulated proliferation and invasiveness of the MCF7 cells may be expected due to the impeded expression of S100-A14 in the combination treatment versus the mono treatments. The enhanced expression of the UPF2-encoded regulator of nonsense transcripts 2 protein in the combination treatment group might be advantageous to overcome doxorubicin resistance in breast cancer cells.

We highlighted the prenylated stilbenes, flavanone, chalcone as potential anticancer metabolites of AP-1 against the MCF7 cells. Finally, AP-1 and its charted metabolites presented a new opportunity to enhance the effectiveness of the breast cancer treatment regimen containing DOX. However, further in vivo and clinical studies are warranted to validate these in vitro findings.

\section{Material and Methods}

\subsection{Chemicals and Preparation of Australian Propolis Extract}

Doxorubicin (DOX) with $98 \%$ purity was purchased from Sigma-Aldrich, New South Wales, Australia. In our recent study, we chemically standardised and identified the key markers of the ethanolic extract of Australian propolis (AP-1) [49]. The same AP-1 extract was utilised in the current study, where the previous study reported the extraction procedure [49].

\subsection{Cell Culture}

The MCF7 human breast adenocarcinoma and fibrocystic breast tissue MCF10A were obtained from the American Type Culture Collection (ATCC: Manassas, VA, USA). Dulbecco's Modified Eagle Medium (DMEM; Lonza, New South Wales, Australia) with $4.5 \mathrm{~g} / \mathrm{L}$ Glucose, L-Glutamine and sodium pyruvate (Lonza Australia Pty Ltd., Mount Waverley, Victoria, Australia) supplemented with 10\% foetal bovine serum (FBS; Interpath, Victoria, Australia) and $100 \mathrm{U} / \mathrm{mL}$ of penicillin and streptomycin (Sigma-Aldrich, New South Wales, Australia) was used to culture the MCF7 at $37{ }^{\circ} \mathrm{C}$ in the presence of $5 \% \mathrm{CO}_{2}$. The RAW 264.7 murine macrophage cell line was cultured using the same conditions except for 5\% FBS in DMEM. DMEM/F12 supplemented with $20 \mathrm{ng} / \mathrm{mL}$ EGF, Caisson DFP18-1LT, $100 \mathrm{ng} / \mathrm{mL}$ cholera toxin, $5 \%$ horse serum, $0.5 \mu \mathrm{g} / \mathrm{mL}$ hydrocortisone, and $10 \mu \mathrm{g} / \mathrm{mL}$ insulin was used to culture the MCF10A cell line at $37^{\circ} \mathrm{C}$ in the presence of $5 \% \mathrm{CO}_{2}$. Viable cells were routinely quantified using the trypan blue exclusion assay with a cell counter (Vi-Cell XR Counter, Beckman Coulter GmbH, Krefeld, Germany).

\subsection{Cell Viability Determination}

Cellular viability was determined using the alamarBlue (resazurin) assay [210,211]. Briefly, in a 96 well plate, $100 \mu \mathrm{L}$ of suspended MCF7 cells were seeded at $1 \times 10^{4} /$ well and incubated at $37^{\circ} \mathrm{C}$ in the presence of $5 \% \mathrm{CO} 2$ overnight to adhere. The cells were treated with different concentrations of AP-1 and DOX and their combinations in different ratios together with the vehicle control ( $0.5 \%$ dimethyl sulfoxide (DMSO)). After $72 \mathrm{~h}$, the medium was removed from the wells, and $100 \mu \mathrm{L}$ of working alamarBlue $(0.1 \mathrm{mg} / \mathrm{mL})$ solution was added to each well and incubated for $4 \mathrm{~h}$ at $37^{\circ} \mathrm{C}$ in the presence of $5 \%$ $\mathrm{CO}_{2}$. The working alamarBlue solution was prepared by 1:10 dilution of freshly prepared stock ( $1 \mathrm{mg} / \mathrm{mL}$ resazurin in phosphate buffer saline) using FBS free media. Using a microplate reader (BMG CLARIOstar, Victoria, Australia), the fluorescence was measured with excitation wavelength at $555 \mathrm{~nm}$ and emission wavelength at $595 \mathrm{~nm}$. Cell viability was determined as a percentage of the vehicle control.

4.4. Biochemometric and LCMS-Driven Metabolomic Identification of Anticancer Metabolites of AP-1 in the MCF7 Human Breast Adenocarcinoma Cells

AP-1 was fractionated using a preparative HPLC Shimadzu system (LC20AP Preppumps, SPD-20A Prominence UV/Vis detector, SIL-20A HT autosampler with FRC-10A fraction collector). Luna ${ }^{\circledR} 5 \mu \mathrm{m} \mathrm{C18} 100 \mathrm{~A}^{\circ}$, LC column $(250 \mathrm{~mm} \times 21.2 \mathrm{~mm})$ was utilised (Phenomenex, Torrance, CA, USA). Water and acetonitrile were used as mobile phase A and $B$, respectively. Gradient incline of acetonitrile at a flow rate of $15 \mathrm{~mL} \mathrm{~min}{ }^{-1}$ was 
implemented with an initial 20\% B, then the following gradient was used; at 25-20 min (40-60\%B), 75-100 $\mathrm{min}(70-80 \% \mathrm{~B})$, and $125-150 \mathrm{~min}(90-100 \% \mathrm{~B})$ and washed for $10 \mathrm{~min}$ and equilibrated at $20 \% \mathrm{~B}$ for another $10 \mathrm{~min}$. Two $\mathrm{mL}$ samples $\left(250 \mu \mathrm{g} \mathrm{mL}{ }^{-1}\right.$ in acetonitrile) were injected, and five fractions were collected at 25 min intervals (Figure S7). The AP-1 fractions were dried and evaluated for their anticancer activity against MCF7. The fractions were analysed using ultra-high-performance liquid chromatography (UPLC) coupled with a quadrupole time of flight (qTOF) analyser using Acquity UPLC (Waters, Milford, MA, USA) coupled with SYNAPT G2-S (Waters, Milford, MA, USA) mass spectrophotometer. Five $\mu \mathrm{L}$ of the fractions $\left(1 \mathrm{mgmL}^{-1}\right.$ in acetonitrile) was injected at $400 \mu \mathrm{L} \mathrm{min}{ }^{-1}$. Chromatographic separation was achieved using ACQUITY UPLC HSS T3 Column $(1.8 \mu \mathrm{m}$, $2.1 \mathrm{~mm} \times 150 \mathrm{~mm}$; Waters Corporation, Milford, MA, USA). The column temperature was kept at $45^{\circ} \mathrm{C}$, and gradient elution was implemented utilizing $0.1 \%$ formic acid solution of both water (A) and acetonitrile (B). Initially, $20 \%$ of the mobile phase B was used, and linearly inclined as the following gradient: $30-40 \%$ B (5-15 min), 40-60\% B (15-20 min), and $60-90 \%$ B (20-28 min) and finally declined to $20 \%$ B for $30 \mathrm{~min}$. G2-S high definition mass spectrometer (HDMS) (Waters Corp, Manchester, UK) equipped with Z-spray source controlled by MassLynx v4.1 was used for mass spectrometry analysis in negative ESI ionization mode using HDMS mode of operation. The scanning mode parameters were: source temperature: $120^{\circ} \mathrm{C}$, desolvation temperature: $500{ }^{\circ} \mathrm{C}$, cone gas flow: $50 \mathrm{~L} / \mathrm{h}$, desolvation gas flow: $1000 \mathrm{~L} / \mathrm{h}$, collision energy ramp: $20-50 \mathrm{eV}$, capillary voltage: $2.5 \mathrm{kV}$, and acquisition mass range: $50-1200 \mathrm{~m} / \mathrm{z}$.

Data were acquired in a profile mode and corrected with lock mass spray switching between the samples and external reference, allowing the MassLynx to ensure mass analysis accuracy continuously [212,213]. Leucine enkephaline $\left(1 \mathrm{ng} \mu \mathrm{L}^{-1}\right)$ was used as an external reference in 1:1 acetonitrile-water containing $0.1 \%$ formic acid at a flow rate of $5 \mu \mathrm{L} / \mathrm{min}$ via a LockSpray interface, generating a reference ion for negative ion mode $[\mathrm{M}-\mathrm{H}]^{-}$of $554.261 \mathrm{~m} / \mathrm{z}$.

Progenesis QI software (Waters Corp., Milford, MA, USA) was used for data processing, and features were considered reproducible if their coefficient of variation (CV) among the samples were $<25 \%$, and the fold change $(\mathrm{FC})>2$, ANOVA $p$-value and $\mathrm{Q}$ value $<0.01$ against the blank samples. Orthogonal partial least-squares discriminant analyses (OPLSDA) analyses were implemented to identify the discriminatory metabolites in the active fractions against inactive or less active ones using SIMCA version 14.1 (Umetrics, Umea, Sweden). Progenesis QI was used for putative identification of metabolites of interest by comparison with metabolomic profiling CCS library, LipidBlast, and Progenesis Metascape imported databases including HMDB, MONA, LipidMaps and GNPS and Chemspider imported data sources such as KEGG, NIST, in addition to reference literature and CRC dictionary of natural products database.

\subsection{Synergy Quantification of AP-1 and DOX Combinations against the MCF7 Human Breast Adenocarcinoma Cells}

The potential interactions between AP-1 and DOX were analysed using the combination index (CI) model and the DrugComb portal (https: / / drugcomb.fimm.fi/, accessed on 25 May 2021). CompuSyn version 2.0 (Biosoft, US) was used for the CI calculations based on the median-effect equation, which was derived from mass action law [214-216]. In the current study, nine pairwise combinations of DOX with AP-1 were studied in constant ratio design with a six-points dose-response curve in 2:1 serial dilution $(n=3)$ using the CI model. Furthermore, the combinations were also evaluated in a checkerboard design $(n=3)$ using drugComb [217]. The response data obtained from the CI model were further analysed in DrugComb, where the mean percentage of cell inhibition and the concentrations of the combined drugs were used as input for synergy scores in different models and combination sensitivity score (CSS) evaluation. 


\subsection{Reactive Oxygen Species (ROS) Assay}

The intracellular ROS level in the MCF7 cells treated with AP-1, DOX and their most synergistic combination was evaluated using the DCFDA $\left(2^{\prime}, 7^{\prime}\right.$-dichlorofluorescein diacetate) Cellular ROS Detection Assay Kit (\#ab113851; Abcam, Victoria, Australia) according to the manufacturer's protocol. DCFDA is a fluorogenic dye that measures hydroxyl, peroxyl and other ROS activity within the cell. Briefly, in a 96 well-plate, the MCF7 cells were seeded at $2.5 \times 10^{4}$ cells/well and incubated at $37^{\circ} \mathrm{C}$ in the presence of $5 \% \mathrm{CO}_{2}$ overnight to adhere. The next day, the media was discarded, and cells were washed with $100 \mu \mathrm{L} /$ well of the $1 \mathrm{X}$ buffer. Then the cells were incubated at $37^{\circ} \mathrm{C}$ with $100 \mu \mathrm{L}$ per well of $20 \mu \mathrm{M}$ DCFDA solution for $45 \mathrm{~min}$ in the dark. Then, the DCFDA solution was discarded, and cells were washed with $100 \mu \mathrm{L}$ per well of $1 \mathrm{X}$ buffer and treated with different concentrations of AP-1, DOXO, synergistic combinations, and positive control tert-Butyl hydroperoxide (TBHP) for $4 \mathrm{~h}$. The plate was measured immediately at Ex $/ \mathrm{Em}=485 / 535 \mathrm{~nm}$ in endpoint by using a microplate spectrophotometer (BMG CLARIOstar, Victoria, Australia). The assay protocol is based on the diffusion of DCFDA into the cell, which is then deacetylated by cellular esterases to a non-fluorescent compound, which is then ROS oxidised into $2^{\prime}, 7^{\prime}$-dichlorofluorescein (DCF) that can be detected using a fluorescence plate reader. Blank readings for treatments were subtracted, and the percentage of ROS production was calculated relative to the negative control (no treatment).

\subsection{Flow Cytometric Analyses of Apoptosis in the MCF7 Human Breast Adenocarcinoma Cells Using Annexin V-CF Blue and 7-Aminoactinomycin D (7AAD)}

The apoptotic profiles of the MCF7 human breast adenocarcinoma cells after treatment with AP-1, DOX and their most synergistic combination were analysed using the Abcam Apoptosis Detection Kit (\#ab214663, Abcam, Victoria, Australia) as per the manufacturer's protocol. Briefly, the MCF7 cells were cultured in T75 cell culture flasks with a seeding density of $1 \times 10^{6}$ and exposed to vehicle control (DMSO), AP-1 $\left(100 \mu \mathrm{g} \mathrm{mL}{ }^{-1}\right)$, DOX $\left(0.29 \mu \mathrm{g} \mathrm{mL}^{-1}\right)$ and the synergistic combinations of AP-1 and DOX $\left(50 \mu \mathrm{g} \mathrm{mL}^{-1}\right.$ : $0.145 \mu \mathrm{g} \mathrm{mL}^{-1}$ ). After $24 \mathrm{~h}$, the cell culture media was collected, and each cell flask was treated with $0.25 \% w / v$ of trypsin for $3 \mathrm{~min}$ at $37^{\circ} \mathrm{C}$. Trypsin was neutralised with an equal volume of $10 \%$ FBS-containing media and combined with the previously collected media. Cell pellets were collected by centrifugation at $500 \times g$ for $5 \mathrm{~min}$ at room temperature (RT), washed twice in PBS, resuspended in $1 \mathrm{~mL}$ PBS, and centrifuged at $500 \times g$ for another $5 \mathrm{~min}$. Harvested cell pellets of all treatment groups were immediately resuspended in $0.5 \mathrm{~mL} 1 \times$ binding buffer, and to each $100 \mu \mathrm{L}$ of cell suspension, $5 \mu \mathrm{L}$ of annexin V-CF blue and 7-AAD staining solutions were added. Cells were incubated in dark at RT for $15 \mathrm{~min}$, and then $400 \mu \mathrm{L}$ of $1 \times$ binding buffer was added. The cells were then analysed by ACEA Biosciences Novocyte 3000 flow cytometer (ACEA Biosciences Inc., San Diego, CA, USA). The NovoExpress (ver 1.5.0, ACEA Biosciences Inc., USA) software was implemented for analysis and processing where cells were gated on FSC vs. SSC to exclude the debris near the origin and cell aggregates. This was followed by gating on dot-plots of Annexin V-CF in Pacific Blue vs. 7-AAD fluorescence in PerCP with a quadrant placed indicating live cells (+Annexin $\mathrm{V}$ and-7-AAD) in the lower-left quadrant, early apoptotic cells (+Annexin $\mathrm{V}$ and -7-AAD) in the lower-right quadrant, late apoptotic cells (+Annexin $\mathrm{V}$ and +7-AAD) in the upper-right quadrant and necrotic cells (-Annexin V and 7-AAD) in the upper-left quadrant. Finally, cell percentage data in each quadrant after different treatments $(n=4)$ were exported to GraphPad Prism (version 9.0, San Diego, CA, USA) for statistical analysis and visualisation.

\subsection{Human Apoptosis Proteomic Array}

\subsubsection{Cell Culture, Treatment, and Protein Extraction}

The MCF7 cells were cultured in T75 cell culture flasks with a seeding density of $1.0 \times 10^{6}$ cells and incubated overnight at $37^{\circ} \mathrm{C}$ in the presence of $5 \% \mathrm{CO}_{2}$. The media was aspirated and replaced with fresh media containing $0.5 \%$ DMSO as the vehicle control, 
$100 \mu \mathrm{g} \mathrm{mL} \mathrm{L}^{-1} \mathrm{AP}-1,0.29 \mu \mathrm{g} \mathrm{mL}^{-1} \mathrm{DOX}$ and synergistic combination $\left(100 \mu \mathrm{g} \mathrm{mL} \mathrm{m}^{-1} \mathrm{AP}-1\right.$, and $0.29 \mu \mathrm{g} \mathrm{mL}{ }^{-1} \mathrm{DOX}$ ), then incubated for $24 \mathrm{~h}$ at $37^{\circ} \mathrm{C}$ in the presence of $5 \% \mathrm{CO}_{2}$. The cell culture media was collected, and each cell flask was treated with $0.25 \% w / v$ trypsin for $3 \mathrm{~min}$ at $37^{\circ} \mathrm{C}$. Trypsin was neutralised with an equal volume of $10 \%$ FBS-containing media and combined with the previously collected media. The cells were centrifuged at $500 \times g$ for $5 \mathrm{~min}$ at RT, and the pellets were washed twice with ice-cold PBS and centrifuged again at $500 \times g$ for $5 \mathrm{~min}$. The cell pellets were then resuspended in $100 \mu \mathrm{L}$ lysis buffer included in proteome profiler human apoptosis array kit (ARY009, R\&D Systems, NE Minneapolis, MN, USA). The lysis buffer was freshly supplemented with cOmplete Protease Inhibitor Cocktail $^{\mathrm{TM}}$ (\#04693116001; Roche UK purchased from Sigma-Aldrich, New South Wales, Australia). Cell pellets were left on ice for $20 \mathrm{~min}$ with occasional vortexing for $10 \mathrm{sec}$ every $5 \mathrm{~min}$, then centrifuged at $14,000 \mathrm{rpm}$ for $20 \mathrm{~min}$ at $4{ }^{\circ} \mathrm{C}$, and the lysate was collected.

\subsubsection{Protein Quantification}

Pierce $^{\mathrm{TM}}$ Rapid Gold BCA Protein Assay Kit (\#A53226, ThermoScientific, Waltham, MA, USA) was used to determine the protein concentration of the cell lysate in triplicates against bovine serum albumin (BSA) standard according to the manufacturer's protocol. Briefly, $1 \mu \mathrm{L}$ of each sample replicate was 1:20 diluted in the water together with $20 \mu \mathrm{L}$ of each standard, were placed in a 96-well plate with $200 \mu \mathrm{L}$ of working reagent per well. Samples were diluted to be within the operating range of $20-2000 \mu \mathrm{g} \mathrm{mL}^{-1}$. The plate was mixed thoroughly on a plate shaker for $30 \mathrm{~s}$ and incubated at room temperature for $5 \mathrm{~min}$, and then the absorbance was measured within $20 \mathrm{~min}$ at $480 \mathrm{~nm}$ using a microplate spectrophotometer (BMG CLARIOstar, Victoria, Australia). The blank absorbance was subtracted from all other readings of standards and samples, and sample concentration was determined against the established BSA standard calibration curve. Samples were stored at $-80^{\circ} \mathrm{C}$ for further analysis.

\subsubsection{Apoptosis Proteome Array Analysis}

A proteome profiler ${ }^{\mathrm{TM}}$ human apoptosis array kit (\#ARY009, R\&D Systems, NE Minneapolis, MN, USA) was used according to the manufacturer's instructions to analyse the expression level of 35 apoptosis-related proteins in the MCF7 cell lysates treated with AP-1, DOX, their synergistic combination and the vehicle control. Briefly, each array was blocked ( $2 \mathrm{~mL}$ array buffer 1$)$ for $1 \mathrm{~h}$, then incubated with the MCF7 cell lysates (350 $\mu \mathrm{g}$ total protein) for $2 \mathrm{~h}$ at $\mathrm{RT}$ and washed three times (10 min each) on a rocking platform shaker. The arrays were mixed with antibody cocktails and incubated for $1 \mathrm{~h}$, then washed and incubated for $30 \mathrm{~min}$ with Streptavidin-HRP. The arrays were rewashed three times (10 min each) and incubated with the Chemi Reagent mix for $1 \mathrm{~min}$. The extra Chemi Reagent was wiped, and blot images were captured using an ImageQuant ${ }^{\mathrm{TM}}$ LAS 500 image system (GE, Healthcare, Bio-Sciences, Uppsala, Sweden) with 2 min of manual exposure. The pixel densities of the developed spots were analysed using Image [218], and mean negative control pixel intensities (PBS) were subtracted from all values followed by pairwise comparisons of the expression data of single treatments versus the control array (MCF7 cell treated with $0.5 \%$ DMSO) or the synergistic combination versus single treatments. All expression data were quantile normalised, log-transformed, and Pareto-scaled before any statistical analyses. Statistical analysis was performed using Metaboanalyst 5.0 [219] for the selection of significantly dysregulated proteins (Absolute fold change (FC) of 1.3 and $p$-value $\geq 0.05)$ after different treatments in pairwise comparisons.

\subsection{Bottom-Up Label-Free Quantification Proteomic Study of the MCF7 Cell Lysates after Treatment with the Most Synergistic Combination}

\subsubsection{Cell Culture, Treatment and Protein Extraction}

The MCF7 cells were cultured in T75 flasks at a seeding density of $1.0 \times 10^{6}$ cells and incubated overnight at $37^{\circ} \mathrm{C}$ in the presence of $5 \% \mathrm{CO}_{2}$. The media was aspirated and replaced with fresh media containing $0.5 \% \mathrm{DMSO}$ as the vehicle control, $100 \mu \mathrm{g} \mathrm{mL}{ }^{-1} \mathrm{AP}-1$, 
$0.29 \mu \mathrm{g} \mathrm{mL}^{-1}$ DOX and synergistic combination $\left(100 \mu \mathrm{gL}^{-1} \mathrm{AP}-1\right.$, and $0.29 \mu \mathrm{g} \mathrm{mL}^{-1}$ DOX), and incubated for $24 \mathrm{~h}$ at $37^{\circ} \mathrm{C}$ in the presence of $5 \% \mathrm{CO}_{2}$. The cell culture media was collected, and each cell flask was treated with $0.25 \% w / v$ trypsin for $3 \mathrm{~min}$ at $37^{\circ} \mathrm{C}$. Trypsin was neutralised with an equal volume of $10 \%$ FBS-containing media and combined with the previously collected media. The cells were centrifuged at $500 \times g$ for $5 \mathrm{~min}$ at RT, and the pellets were washed twice with ice-cold PBS and centrifuged again at $500 \times g$ for $5 \mathrm{~min}$. The cell pellets were then resuspended in $100 \mu \mathrm{L}$ lysis buffer with $1 \mu \mathrm{L}$ of universal nuclease included in EasyPep ${ }^{\mathrm{TM}}$ Mini MS Sample Prep Kit (ThermoFisher Scientific, USA). Halt $^{\mathrm{TM}}$ Protease and Phosphatase Inhibitor Cocktail, EDTA-Free (Thermo Scientific, USA) were used at $10 \mu \mathrm{L} \mathrm{mL}^{-1}$ of lysis buffer to prevent enzymatic protein degradation during extraction and purification protocols. This cocktail is fully compatible with Pierce cell lysis buffers can be used safely in mass spectrometry (MS). The cells were pipetted up and down 10-15 times until sample viscosity is reduced and left in ice for $20 \mathrm{~min}$, then centrifuged at $14,000 \mathrm{rpm}$ for $20 \mathrm{~min}$ at $4{ }^{\circ} \mathrm{C}$, and the lysate was collected.

\subsubsection{Peptides Preparation and Clean Up}

The cell lysates were quantified as in Section 4.8.2, and $100 \mu \mathrm{g}$ of protein samples were used for chemical and enzymatic sample processing according to the manufacturer protocol (EasyPep ${ }^{\mathrm{TM}}$ Mini MS Sample Prep Kit; ThermoFisher Scientific, USA). The final volume was adjusted to $100 \mu \mathrm{L}$ using lysis buffer in a microcentrifuge tube. $50 \mu \mathrm{L}$ of the reduction and alkylation solutions were added, gently mixed, and incubated at $95{ }^{\circ} \mathrm{C}$ using a heat block for $10 \mathrm{~min}$. The samples are allowed to cool at RT, then $50 \mu \mathrm{L}$ of the reconstituted trypsin/lys-C protease mixture was added to each sample and incubated with shaking at $37^{\circ} \mathrm{C}$ for $3 \mathrm{~h}$. After incubation, $50 \mu \mathrm{L}$ of digestion stop solution was added and mixed gently. Peptides clean up columns were implemented to remove hydrophilic and hydrophobic contaminants where clean peptide samples were dried using a vacuum centrifuge and resuspended in $100 \mu \mathrm{L} 0.1 \%$ formic acid in water for LC-MS analysis.

4.9.3. Label-Free Bottom-Up Quantification via Nano-Ultra High-Performance Liquid Chromatography Coupled with Quadruple Time of Flight Mass Spectrometry (NanoUPLC-qTOF-MS)

Tryptic peptides were analysed using a nanoACQUITY UPLC system (Waters Corp., Milford, MA, USA) coupled to Synapt G2-S high-definition mass spectrometer (HDMS) (Waters Corp., Manchester, UK) operating in positive electron spray ion mode (ESI+) and equipped with hybrid quadrupole time of flight (qTOF) analyser. Mass accuracy was maintained by Waters NanoLockSpray Exact Mass Ionization Source with $100 \mathrm{fg} \mathrm{mL}^{-1}$ Glu-fibrinopeptide B (GFP) Lockspray solution (in 50\% aqueous acetonitrile containing $0.1 \%$ formic acid, lock mass $m / z$ 785.84.26) infused at $0.5 \mu \mathrm{L} \mathrm{min}^{-1}$ and calibrated against a sodium iodide solution. The chromatographic system was equipped with a nanoEase $m / z$ BEH C18 $(1.7 \mu \mathrm{m}, 130 \AA, 75 \mu \mathrm{m} \times 100 \mathrm{~mm}$, Waters Corp., Milford, MA, USA $)$ at $40{ }^{\circ} \mathrm{C}$ and nanoEase $m / z$ Symmetry C18 Trap Column (100 $⿱ ㇒, 5 \mu \mathrm{m}, 180 \mu \mathrm{m} \times 20 \mathrm{~mm}$, Waters Corp., USA). Milli-Q water and acetonitrile (LCMS grade, Merck, Germany) containing 0.1\% formic acid were used as mobile phase $\mathrm{A}$ and $\mathrm{B}$, respectively, with $1 \mu \mathrm{L}$ injection volume at $0.3 \mu \mathrm{L} \mathrm{min}^{-1}$ flow rate throughout $50 \mathrm{~min}$ gradient. Samples were injected into the trapping column at $5 \mu \mathrm{L} \mathrm{min}^{-1}$ at $99 \%$ mobile phase $\mathrm{A}$ for $3 \mathrm{~min}$ before being eluted on the analytical column. The peptides were separated using a chromatographic method where an initial $1 \%$ of mobile phase $\mathrm{B}$ and ramped to $85 \% \mathrm{~B}$ over 50 min with the following gradient: $10 \% \mathrm{~B}$ at $2 \mathrm{~min}, 40 \% \mathrm{~B}$ at $40 \mathrm{~min}$ and $85 \% \mathrm{~B}$ at $42 \mathrm{~min}$. All samples are kept at $4{ }^{\circ} \mathrm{C}$ and were injected in triplicates. The ion source block temperature was set to $80^{\circ} \mathrm{C}$, and capillary voltage was maintained to $3 \mathrm{kV}$. Ions were acquired with $\mathrm{m} / z$ between 50 and 2000, scanning time of 0.5 sec, sample cone voltage and source offset at $30 \mathrm{~V}$, nanoflow gas at $0.3 \mathrm{Bar}$, purge gas at 20 $\mathrm{L} \mathrm{h}^{-1}$ and cone gas flow at $20 \mathrm{~L} \mathrm{~h}^{-1}$. Data independent acquisition (DIA) method by MSE multiplex mode was used for samples acquisition at T-wave collision-induced dissociation cell filled with argon gas with MassLynx Mass Spectrometry Software (Waters Corporation, USA). 


\subsubsection{Data Processing and Availability}

Progenesis QI software (Waters Corporation, Milford, MA, USA) was used to import and further process the MassLynx acquired data. Automatic selection of alignment reference among QC samples was set, and peptides were identified against Uniprot human proteome database (October 2020 version) using the ion accounting method with $250 \mathrm{kDa}$ protein mass maximum. One fragment per peptide or one peptide per protein together with three fragments per protein were set as ion matching requirements using relative quantification implementing the Hi-N method $(n=3)$. Auto peptide and fragment tolerance and less than $4 \%$ FDR were set for search tolerance parameters. Peptides with absolute mass error $>20$ ppm or single charged were further filtered out. Pairwise comparisons of the identified proteins in the treated groups were done against the control group for potential cytotoxic exploration, while the most synergistic combination samples were compared against both DOX and AP-1 -treated samples to elucidate possible synergistic mechanisms.

In each experimental design, proteins with analysis of variance (ANOVA)-derived $p$-value $\leq 0.05$ and q value $\leq 0.01$ with absolute fold change $(\mathrm{FC}) \geq 1.7$ were considered significant and included for further pathway analyses. Differentially expressed proteins identified by the quantitative processing of the LC-MS/MS analysis of the proteome tryptic digestion were analysed by STRING [220], Reactome [221], g:Profiler [222,223] and IMPaLA [224] to identify the relevant pathways responsible for the synergistic effect against the MCF7 cells. The G:SCS algorithm was used for multiple testing corrections in g:profiler platform with an adjusted p-value of 0.05 threshold. The raw and processed data have been deposited to the ProteomeXchange Consortium via the PRoteomics IDEntifications (PRIDE) repository [225] with the dataset identifier PXD026331 and 10.6019/PXD026331.

\subsection{Statistical Analysis}

All statistic comparisons were performed using GraphPad Prism Version 9 (San Diego, CA, USA) except for the apoptotic array and shotgun proteomics study where MetaboAnalyst 5.0 (https:/ / www.metaboanalyst.ca/, accessed on 2 June 2021) were used together with Progenesis QIP (Waters Corporation, Milford, MA, USA) for the shotgun proteomic study. The significance was analysed by ANOVA and $t$-test for multiple and pairwise comparisons, respectively. Data were expressed as a mean \pm SD. The differences between the mean values in the experiments at least $p<0.05$ were considered statistically significant.

Supplementary Materials: The following are available online at https:/ /www.mdpi.com/article/10.339 0/ijms22157840/s1.

Author Contributions: M.A.A.: Conceptualization, methodology, investigation, data curation, writing original draft, review and visualization, D.J.B.: Conceptualization, funding, methodology, supervision, and review, I.R.: supervision, review and data processing, D.C. and C.-G.L.: Conceptualization, funding, review, and supervision. All authors have read and agreed to the published version of the manuscript.

Funding: This research received no direct external funding and the APC was partially funded by NICM Health Research Institute, Western Syndey University, Australia.

Institutional Review Board Statement: Not applicable.

Informed Consent Statement: Not applicable.

Data Availability Statement: Shotgun proteomics data is available in the PRIDE repository with the dataset identifier PXD026331 and DOI; 10.6019/PXD026331. All other data are presented within the article or Supplementary Files 1 and 2.

Acknowledgments: We acknowledge the following funding support: The Maxwell Family Foundation, Australia; NICM Health Research Institute and the Western Sydney University, Australia. M.A.A. would like to acknowledge the Missions sector, Ministry of higher education, Egypt, and Research and Training Program, Western Sydney University, Australia for supporting his PhD research. The authors would like to acknowledge Western Sydney University's Mass Spectrometry Facility for providing access to its instrumentation and assistance of Meena Mikhael (Facility Research Manager, Mass Spectrometry Unit, Western Sydney University) with the MS analyses. 
Conflicts of Interest: As a medical research institute, NICM Health Research Institute receives grants and donations from foundations, universities, government agencies, individuals, and industry. Sponsors and donors also provide untied funding to advance the vision and mission of the institute. The authors declare no conflict of interest.

\section{Abbreviations}

\begin{tabular}{|c|c|}
\hline 7-AAD & 7-aminoactinomycin D \\
\hline $\mathrm{AC}$ & Adriamycin/cyclophosphamide \\
\hline AP-1 & Australian propolis sample 1 \\
\hline Apaf-1 & Apoptotic protease-activating factor 1 \\
\hline ARA & Adriamycin Resistance Associated long non-coding RNA \\
\hline ATM & Ataxia-telangiectasia mutated \\
\hline ATR & Ataxia-telangiectasia and Rad3-related protein \\
\hline Bad & Bcl-2 associated agonist of cell death \\
\hline Bax & BCL2 associated X \\
\hline Bcl-2 & B-cell lymphoma 2 \\
\hline Bcl-XL & B-cell lymphoma-extra large \\
\hline CMF & cyclophosphamide/methotrextate/5-flurouricil \\
\hline CAT & cyclophosphamide/adriamycin/taxanes \\
\hline CI & Combination index \\
\hline cIAP-1 & $\begin{array}{l}\text { Cellular Inhibitor of Apoptosis Protein 1/Baculoviral IAP } \\
\text { repeat-containing } 2\end{array}$ \\
\hline cIAP-2 & Baculoviral IAP repeat containing 3 \\
\hline CSS & Combination sensitivity scores \\
\hline DSBs & Double-strand breaks \\
\hline DOX & Doxorubicin \\
\hline EJC & Exon-junction complex \\
\hline $\mathrm{ER}+$ & Estrogen receptor positive \\
\hline FADD & Fas-associated protein with death domain \\
\hline Fas/TNFRSF6/CD95 & $\begin{array}{l}\text { Fas receptor/tumour necrosis factor receptor superfamily member } 6 \text { / } \\
\text { cluster of differentiation } 95\end{array}$ \\
\hline HER-2 & $\begin{array}{l}\text { Human epidermal growth factor receptor } 2 / \text { Receptor tyrosine-protein } \\
\text { kinase erbB-2 }\end{array}$ \\
\hline HIF- $1 \alpha$ & Hypoxia-inducible factor 1-alpha \\
\hline HO-1/HMOX1/HSP32 & Heme oxygenase 1 \\
\hline $\mathrm{HO}-2 / \mathrm{HMOX} 2$ & Heme oxygenase 2 \\
\hline HSP27 & Heat shock protein 27 \\
\hline HSP60 & Heat shock protein 60 chaperonins \\
\hline HSP70 & Heat shock protein 70 \\
\hline HTRA2/Omi & High-temperature requirement protein A \\
\hline JNK & c-Jun N-terminal kinase \\
\hline IAPs & Inhibitors of apoptosis \\
\hline IGF-1 & Insulin-like growth factor-1 \\
\hline NHEJ & Nonhomologous End-Joining \\
\hline NMD & Nonsense-mediated decay \\
\hline ROS & Reactive oxygen species \\
\hline S & S synergy score \\
\hline VIP & Variable Importance Projection score derived from PLS-Da model \\
\hline TRAIL R1/DR4 & TNF-related apoptosis-inducing ligand receptor 1/Death receptor 4 \\
\hline TRAIL R2/DR5 & TNF-related apoptosis-inducing ligand receptor 2/Death receptor 5 \\
\hline PON2 & Serum paraoxonase/arylesterase 2 \\
\hline p21/CIP1/CDKN1A & cyclin-dependent kinase inhibitor 1 \\
\hline p27/Kip1 & Cyclin-dependent kinase inhibitor 1B \\
\hline TNF RI/TNFRSF1A & $\begin{array}{l}\text { Tumour necrosis factor receptor } 1 \text { /tumour necrosis factor receptor } \\
\text { superfamily member } 1 \mathrm{~A}\end{array}$ \\
\hline XIAP & X-linked inhibitor of apoptosis protein \\
\hline
\end{tabular}




\section{References}

1. Seddon, B.; Strauss, S.J.; Whelan, J.; Leahy, M.; Woll, P.J.; Cowie, F.; Rothermundt, C.; Wood, Z.; Benson, C.; Ali, N.; et al. Gemcitabine and docetaxel versus doxorubicin as first-line treatment in previously untreated advanced unresectable or metastatic soft-tissue sarcomas (GeDDiS): A randomised controlled phase 3 trial. Lancet Oncol. 2017, 18, 1397-1410. [CrossRef]

2. McMeekin, S.; Dizon, D.; Barter, J.; Scambia, G.; Manzyuk, L.; Lisyanskaya, A.; Oaknin, A.; Ringuette, S.; Mukhopadhyay, P.; Rosenberg, J.; et al. Phase III randomized trial of second-line ixabepilone versus paclitaxel or doxorubicin in women with advanced endometrial cancer. Gynecol. Oncol. 2015, 138, 18-23. [CrossRef]

3. Al-Malky, H.S.; Al Harthi, S.E.; Osman, A.M. Major obstacles to doxorubicin therapy: Cardiotoxicity and drug resistance. J. Oncol. Pharm. Pract. 2020, 26, 434-444. [CrossRef]

4. Tap, W.D.; Wagner, A.J.; Schoffski, P.; Martin-Broto, J.; Krarup-Hansen, A.; Ganjoo, K.N.; Yen, C.C.; Abdul Razak, A.R.; Spira, A.; Kawai, A.; et al. Effect of Doxorubicin Plus Olaratumab vs. Doxorubicin Plus Placebo on Survival in Patients With Advanced Soft Tissue Sarcomas: The ANNOUNCE Randomized Clinical Trial. JAMA 2020, 323, 1266-1276. [CrossRef] [PubMed]

5. Blum, J.L.; Flynn, P.J.; Yothers, G.; Asmar, L.; Geyer, C.E., Jr.; Jacobs, S.A.; Robert, N.J.; Hopkins, J.O.; O'Shaughnessy, J.A.; Dang, C.T.; et al. Anthracyclines in Early Breast Cancer: The ABC Trials-USOR 06-090, NSABP B-46-I/USOR 07132, and NSABP B-49 (NRG Oncology). J. Clin. Oncol. 2017, 35, 2647-2655. [CrossRef]

6. Schneeweiss, A.; Mobus, V.; Tesch, H.; Hanusch, C.; Denkert, C.; Lubbe, K.; Huober, J.; Klare, P.; Kummel, S.; Untch, M.; et al. Intense dose-dense epirubicin, paclitaxel, cyclophosphamide versus weekly paclitaxel, liposomal doxorubicin (plus carboplatin in triple-negative breast cancer) for neoadjuvant treatment of high-risk early breast cancer (GeparOcto-GBG 84): A randomised phase III trial. Eur. J. Cancer 2019, 106, 181-192. [CrossRef]

7. Koleini, N.; Kardami, E. Autophagy and mitophagy in the context of doxorubicin-induced cardiotoxicity. Oncotarget 2017, 8, 46663-46680. [CrossRef] [PubMed]

8. Early Breast Cancer Trialists' Collaborative Group (EBCTCG). Effects of chemotherapy and hormonal therapy for early breast cancer on recurrence and 15-year survival: An overview of the randomised trials. Lancet 2005, 365, 1687-1717. [CrossRef]

9. Swain, S.M.; Whaley, F.S.; Ewer, M.S. Congestive heart failure in patients treated with doxorubicin: A retrospective analysis of three trials. Cancer 2003, 97, 2869-2879. [CrossRef]

10. Von Hoff, D.D.; Layard, M.W.; Basa, P.; Davis, H.L., Jr.; Von Hoff, A.L.; Rozencweig, M.; Muggia, F.M. Risk factors for doxorubicinlnduced congestive heart failure. Ann. Intern. Med. 1979, 91, 710-717. [CrossRef] [PubMed]

11. Prasanna, P.L.; Renu, K.; Valsala Gopalakrishnan, A. New molecular and biochemical insights of doxorubicin-induced hepatotoxicity. Life Sci. 2020, 250, 117599. [CrossRef] [PubMed]

12. Renu, K.; Gopalakrishnan, A.V. Deciphering the molecular mechanism during doxorubicin-mediated oxidative stress, apoptosis through Nrf2 and PGC-1 $\alpha$ in a rat testicular milieu. Reprod. Biol. 2019, 19, 22-37. [CrossRef] [PubMed]

13. Renu, K.; Sruthy, K.; Parthiban, S.; Sugunapriyadharshini, S.; George, A.; Tirupathi Pichiah, P.B.; Suman, S.; Abilash, V.; Arunachalam, S. Elevated lipolysis in adipose tissue by doxorubicin via PPAR $\alpha$ activation associated with hepatic steatosis and insulin resistance. Eur. J. Pharmacol. 2019, 843, 162-176. [CrossRef] [PubMed]

14. Renu, K.; Abilash, V.; Tirupathi Pichiah, P.B.; Arunachalam, S. Molecular mechanism of doxorubicin-induced cardiomyopathy-An update. Eur. J. Pharmacol. 2018, 818, 241-253. [CrossRef]

15. Kim, S.H.; Kim, K.J.; Kim, J.H.; Kwak, J.H.; Song, H.; Cho, J.Y.; Hwang, D.Y.; Kim, K.S.; Jung, Y.S. Comparision of doxorubicininduced cardiotoxicity in the ICR mice of different sources. Lab. Anim. Res. 2017, 33, 165-170. [CrossRef]

16. Chatterjee, K.; Zhang, J.; Honbo, N.; Karliner, J.S. Doxorubicin cardiomyopathy. Cardiology 2010, 115, 155-162. [CrossRef]

17. Thomas, S.A. Chemotherapy agents that cause cardiotoxicity. US Pharm. 2017, 42, HS24.

18. Chaudhari, U.; Nemade, H.; Wagh, V.; Gaspar, J.A.; Ellis, J.K.; Srinivasan, S.P.; Spitkovski, D.; Nguemo, F.; Louisse, J.; Bremer, S. Identification of genomic biomarkers for anthracycline-induced cardiotoxicity in human iPSC-derived cardiomyocytes: An in vitro repeated exposure toxicity approach for safety assessment. Arch. Toxicol. 2016, 90, 2763-2777. [CrossRef]

19. Cao, X.; Hou, J.; An, Q.; Assaraf, Y.G.; Wang, X. Towards the overcoming of anticancer drug resistance mediated by p53 mutations. Drug Resist. Updates 2020, 49, 100671. [CrossRef]

20. Chen, C.; Lu, L.; Yan, S.; Yi, H.; Yao, H.; Wu, D.; He, G.; Tao, X.; Deng, X. Autophagy and doxorubicin resistance in cancer. Anticancer Drugs 2018, 29, 1-9. [CrossRef] [PubMed]

21. Niu, W.; Xiao, Q.; Wang, X.; Zhu, J.; Li, J.; Liang, X.; Peng, Y.; Wu, C.; Lu, R.; Pan, Y.; et al. A Biomimetic Drug Delivery System by Integrating Grapefruit Extracellular Vesicles and Doxorubicin-Loaded Heparin-Based Nanoparticles for Glioma Therapy. Nano Lett. 2021, 21, 1484-1492. [CrossRef] [PubMed]

22. Ruzycka-Ayoush, M.; Kowalik, P.; Kowalczyk, A.; Bujak, P.; Nowicka, A.M.; Wojewodzka, M.; Kruszewski, M.; Grudzinski, I.P. Quantum dots as targeted doxorubicin drug delivery nanosystems. Cancer Nanotechnol. 2021, 12, 1-27.

23. Gabizon, A.A.; Patil, Y.; La-Beck, N.M. New insights and evolving role of pegylated liposomal doxorubicin in cancer therapy. Drug Resist. Update 2016, 29, 90-106. [CrossRef] [PubMed]

24. Tan, B.L.; Norhaizan, M.E. Curcumin Combination Chemotherapy: The Implication and Efficacy in Cancer. Molecules 2019, 24, 2527. [CrossRef] [PubMed]

25. Mohammadi, M.; Arabi, L.; Alibolandi, M. Doxorubicin-loaded composite nanogels for cancer treatment. J. Control. Release 2020, 328, 171-191. [CrossRef] [PubMed] 
26. Makwana, V.; Karanjia, J.; Haselhorst, T.; Anoopkumar-Dukie, S.; Rudrawar, S. Liposomal doxorubicin as targeted delivery platform: Current trends in surface functionalization. Int. J. Pharm. 2021, 593, 120117. [CrossRef]

27. Borisev, I.; Mrdanovic, J.; Petrovic, D.; Seke, M.; Jovic, D.; Srdenovic, B.; Latinovic, N.; Djordjevic, A. Nanoformulations of doxorubicin: How far have we come and where do we go from here? Nanotechnology 2018, 29, 332002. [CrossRef]

28. Yarmohammadi, F.; Rezaee, R.; Karimi, G. Natural compounds against doxorubicin-induced cardiotoxicity: A review on the involvement of Nrf2/ARE signaling pathway. Phytother. Res. PTR 2021, 35, 1163-1175. [CrossRef]

29. Alsherbiny, M.A.; Abd-Elsalam, W.H.; El Badawy, S.A.; Taher, E.; Fares, M.; Torres, A.; Chang, D.; Li, C.G. Ameliorative and protective effects of ginger and its main constituents against natural, chemical and radiation-induced toxicities: A comprehensive review. Food Chem. Toxicol. 2019, 123, 72-97. [CrossRef]

30. Alsherbiny, M.A.; Li, C.G. Medicinal cannabis-Potential drug interactions. Medicines 2019, 6, 3. [CrossRef]

31. Palmer, A.C.; Sorger, P.K. Combination Cancer Therapy Can Confer Benefit via Patient-to-Patient Variability without Drug Additivity or Synergy. Cell 2017, 171, 1678-1691.e13. [CrossRef]

32. Keith, C.T.; Borisy, A.A.; Stockwell, B.R. Multicomponent therapeutics for networked systems. Nat. Rev. Drug Discov. 2005, 4, 71-78. [CrossRef] [PubMed]

33. Zimmermann, G.R.; Lehar, J.; Keith, C.T. Multi-target therapeutics: When the whole is greater than the sum of the parts. Drug Discov. Today 2007, 12, 34-42. [CrossRef] [PubMed]

34. Yeh, P.J.; Hegreness, M.J.; Aiden, A.P.; Kishony, R. Drug interactions and the evolution of antibiotic resistance. Nat. Rev. Microbiol. 2009, 7, 460-466. [CrossRef] [PubMed]

35. Meyer, C.T.; Wooten, D.J.; Lopez, C.F.; Quaranta, V. Charting the Fragmented Landscape of Drug Synergy. Trends Pharm. Sci. 2020, 41, 266-280. [CrossRef]

36. Vlot, A.H.; Aniceto, N.; Menden, M.P.; Ulrich-Merzenich, G.; Bender, A. Applying drug synergy metrics to oncology combination screening data: Agreements, disagreements and pitfalls. Drug Discov. Today 2019, 24, 2286-2298. [CrossRef]

37. Loewe, S. The problem of synergism and antagonism of combined drugs. Arzneimittelforschung 1953, 3, $285-290$.

38. Yadav, B.; Wennerberg, K.; Aittokallio, T.; Tang, J. Searching for drug synergy in complex dose-response landscapes using an interaction potency model. Comput. Struct. Biotechnol. J. 2015, 13, 504-513. [CrossRef]

39. Berenbaum, M.C. What is synergy? Pharmacol. Rev. 1989, 41, 93-141.

40. Bliss, C.I. The Toxicity of Poisons Applied Jointly1. Ann. Appl. Biol. 1939, 26, 585-615. [CrossRef]

41. O'Neil, J.; Benita, Y.; Feldman, I.; Chenard, M.; Roberts, B.; Liu, Y.; Li, J.; Kral, A.; Lejnine, S.; Loboda, A.; et al. An Unbiased Oncology Compound Screen to Identify Novel Combination Strategies. Mol. Cancer Ther. 2016, 15, 1155-1162. [CrossRef] [PubMed]

42. Gilvary, C.; Dry, J.R.; Elemento, O. Multi-Task learning predicts drug combination synergy in cells and in the clinic. bioRxiv 2019, 576017. [CrossRef]

43. Hosseini, A.; Hosseinzadeh, H. Antidotal or protective effects of Curcuma longa (turmeric) and its active ingredient, curcumin, against natural and chemical toxicities: A review. Biomed. Pharmacother. 2018, 99, 411-421. [CrossRef] [PubMed]

44. Tavakkoli, A.; Ahmadi, A.; Razavi, B.M.; Hosseinzadeh, H. Black Seed (Nigella sativa) and its Constituent Thymoquinone as an Antidote or a Protective Agent Against Natural or Chemical Toxicities. Iran. J. Pharm. Res. 2017, 16, 2-23. [PubMed]

45. Fanoudi, S.; Alavi, M.S.; Karimi, G.; Hosseinzadeh, H. Milk thistle (Silybum marianum) as an antidote or a protective agent against natural or chemical toxicities: A review. Drug Chem. Toxicol. 2020, 43, 240-254. [CrossRef]

46. Dorri, M.; Hashemitabar, S.; Hosseinzadeh, H. Cinnamon (Cinnamomum zeylanicum) as an antidote or a protective agent against natural or chemical toxicities: A review. Drug Chem. Toxicol. 2018, 41, 338-351. [CrossRef] [PubMed]

47. Mohammadzadeh, N.; Mehri, S.; Hosseinzadeh, H. Berberis vulgaris and its constituent berberine as antidotes and protective agents against natural or chemical toxicities. Iran. J. Basic Med. Sci. 2017, 20, 538-551. [CrossRef]

48. Rameshrad, M.; Razavi, B.M.; Hosseinzadeh, H. Protective effects of green tea and its main constituents against natural and chemical toxins: A comprehensive review. Food Chem. Toxicol. 2017, 100, 115-137. [CrossRef]

49. Bhuyan, D.J.; Alsherbiny, M.A.; Low, M.N.; Zhou, X.; Kaur, K.; Li, G.; Li, C.G. Broad-Spectrum pharmacological activity of Australian propolis and metabolomic-driven identification of marker metabolites of propolis samples from three continents. Food Funct. 2021, 12, 2498-2519. [CrossRef]

50. Kocot, J.; Kielczykowska, M.; Luchowska-Kocot, D.; Kurzepa, J.; Musik, I. Antioxidant Potential of Propolis, Bee Pollen, and Royal Jelly: Possible Medical Application. Oxidative Med. Cell. Longev. 2018, 2018, 7074209. [CrossRef]

51. Chiu, H.F.; Han, Y.C.; Shen, Y.C.; Golovinskaia, O.; Venkatakrishnan, K.; Wang, C.K. Chemopreventive and Chemotherapeutic Effect of Propolis and Its Constituents: A Mini-review. J. Cancer Prev. 2020, 25, 70-78. [CrossRef]

52. Patel, S. Emerging Adjuvant Therapy for Cancer: Propolis and its Constituents. J. Diet. Suppl. 2016, 13, 245-268. [CrossRef]

53. Abu-Mellal, A.; Koolaji, N.; Duke, R.K.; Tran, V.H.; Duke, C.C. Prenylated cinnamate and stilbenes from Kangaroo Island propolis and their antioxidant activity. Phytochemistry 2012, 77, 251-259. [CrossRef] [PubMed]

54. Duke, C.C.; Tran, V.H.; Duke, R.K.; Abu-Mellal, A.; Plunkett, G.T.; King, D.I.; Hamid, K.; Wilson, K.L.; Barrett, R.L.; Bruhl, J.J. A sedge plant as the source of Kangaroo Island propolis rich in prenylated p-coumarate ester and stilbenes. Phytochemistry 2017, 134, 87-97. [CrossRef] [PubMed]

55. El-Bassuony, A.; AbouZid, S. A new prenylated flavanoid with antibacterial activity from propolis collected in Egypt. Nat. Prod. Commun. 2010, 5, 43-45. [CrossRef] [PubMed] 
56. Omar, R.M.; Igoli, J.; Gray, A.I.; Ebiloma, G.U.; Clements, C.; Fearnley, J.; Ebel, R.A.; Zhang, T.; De Koning, H.P.; Watson, D.G. Chemical characterisation of Nigerian red propolis and its biological activity against Trypanosoma Brucei. Phytochem. Anal. 2016, 27, 107-115. [CrossRef] [PubMed]

57. Trusheva, B.; Popova, M.; Koendhori, E.B.; Tsvetkova, I.; Naydenski, C.; Bankova, V. Indonesian propolis: Chemical composition, biological activity and botanical origin. Nat. Prod. Res. 2011, 25, 606-613. [CrossRef] [PubMed]

58. Kumazawa, S.; Goto, H.; Hamasaka, T.; Fukumoto, S.; Fujimoto, T.; Nakayama, T. A new prenylated flavonoid from propolis collected in Okinawa, Japan. Biosci. Biotechnol. Biochem. 2004, 68, 260-262. [CrossRef]

59. Chen, C.N.; Wu, C.L.; Lin, J.K. Propolin C from propolis induces apoptosis through activating caspases, Bid and cytochrome $\mathrm{C}$ release in human melanoma cells. Biochem. Pharmacol. 2004, 67, 53-66. [CrossRef]

60. Mukaide, K.; Honda, S.; Vongsak, B.; Kumazawa, S. Prenylflavonoids from propolis collected in Chiang Mai, Thailand. Phytochem. Lett. 2021, 43, 88-93. [CrossRef]

61. Raghukumar, R.; Vali, L.; Watson, D.; Fearnley, J.; Seidel, V. Antimethicillin-resistant Staphylococcus aureus (MRSA) activity of 'pacific propolis' and isolated prenylflavanones. Phytother. Res. 2010, 24, 1181-1187. [CrossRef] [PubMed]

62. Inui, S.; Hosoya, T.; Shimamura, Y.; Masuda, S.; Ogawa, T.; Kobayashi, H.; Shirafuji, K.; Moli, R.T.; Kozone, I.; Shin-Ya, K. Solophenols B-D and Solomonin: New Prenylated Polyphenols Isolated from Propolis Collected from The Solomon Islands and Their Antibacterial Activity. J. Agric. Food Chem. 2012, 60, 11765-11770. [CrossRef] [PubMed]

63. Arvouet-Grand, A.; Lejeune, B.; Bastide, P.; Pourrat, A.; Privat, A.M.; Legret, P. Propolis extract. I. Acute toxicity and determination of acute primary cutaneous irritation index. J. Pharm. Belg. 1993, 48, 165-170.

64. Schmidt, J.; Buchmann, S.J.H. Other Products of the Hive. The Hive and the Honey Bee; Dadant and Sons: Hamilton, IL, USA, 1992; pp. 927-987.

65. Burdock, G.J.F. Review of the biological properties and toxicity of bee propolis (propolis). J. Food Chem. Toxicol. 1998, 36, $347-363$. [CrossRef]

66. Nair, A.B.; Jacob, S. A simple practice guide for dose conversion between animals and human. J. Basic Clin. Pharm. 2016, 7, 27. [CrossRef] [PubMed]

67. Zeraik, M.L.; Pauli, I.; Dutra, L.A.; Cruz, R.S.; Valli, M.; Paracatu, L.C.; de Faria, C.; Ximenes, V.F.; Regasini, L.O.; Andricopulo, A.D.; et al. Identification of a Prenyl Chalcone as a Competitive Lipoxygenase Inhibitor: Screening, Biochemical Evaluation and Molecular Modeling Studies. Molecules 2021, 26, 2205. [CrossRef] [PubMed]

68. Miranda, C.L.; Stevens, J.F.; Ivanov, V.; McCall, M.; Frei, B.; Deinzer, M.L.; Buhler, D.R. Antioxidant and prooxidant actions of prenylated and nonprenylated chalcones and flavanones in vitro. J. Agric. Food Chem. 2000, 48, 3876-3884. [CrossRef]

69. Venturelli, S.; Burkard, M.; Biendl, M.; Lauer, U.M.; Frank, J.; Busch, C. Prenylated chalcones and flavonoids for the prevention and treatment of cancer. Nutrition 2016, 32, 1171-1178. [CrossRef]

70. Miranda, C.L.; Aponso, G.L.M.; Stevens, J.F.; Deinzer, M.L.; Buhler, D.R. Prenylated chalcones and flavanones as inducers of quinone reductase in mouse Hepa 1c1c7 cells. Cancer Lett. 2000, 149, 21-29. [CrossRef]

71. Go, M.L.; Wu, X.; Liu, X.L. Chalcones: An update on cytotoxic and chemoprotective properties. Curr. Med. Chem. 2005, 12, 481-499. [CrossRef]

72. Djoumbou-Feunang, Y.; Pon, A.; Karu, N.; Zheng, J.; Li, C.; Arndt, D.; Gautam, M.; Allen, F.; Wishart, D.S. CFM-ID 3.0: Significantly Improved ESI-MS/MS Prediction and Compound Identification. Metabolites 2019, 9, 72. [CrossRef]

73. Chou, T.-C. The combination index $(\mathrm{CI}<1)$ as the definition of synergism and of synergy claims. Synergy 2018, 7, 49-50.

74. Doroshow, J.H.; Simon, R.M. On the Design of Combination Cancer Therapy. Cell 2017, 171, 1476-1478. [CrossRef] [PubMed]

75. Malyutina, A.; Majumder, M.M.; Wang, W.; Pessia, A.; Heckman, C.A.; Tang, J. Drug combination sensitivity scoring facilitates the discovery of synergistic and efficacious drug combinations in cancer. PLoS Comput. Biol. 2019, 15, e1006752. [CrossRef]

76. Wu, W.S. The signaling mechanism of ROS in tumor progression. Cancer Metastasis Rev. 2006, 25, 695-705. [CrossRef]

77. Arfin, S.; Jha, N.K.; Jha, S.K.; Kesari, K.K.; Ruokolainen, J.; Roychoudhury, S.; Rathi, B.; Kumar, D. Oxidative Stress in Cancer Cell Metabolism. Antioxidants 2021, 10, 642. [CrossRef]

78. Sarmiento-Salinas, F.L.; Delgado-Magallon, A.; Montes-Alvarado, J.B.; Ramirez-Ramirez, D.; Flores-Alonso, J.C.; CortesHernandez, P.; Reyes-Leyva, J.; Herrera-Camacho, I.; Anaya-Ruiz, M.; Pelayo, R.; et al. Breast Cancer Subtypes Present a Differential Production of Reactive Oxygen Species (ROS) and Susceptibility to Antioxidant Treatment. Front. Oncol. 2019, 9, 480. [CrossRef] [PubMed]

79. Kurbacher, C.M.; Wagner, U.; Kolster, B.; Andreotti, P.E.; Krebs, D.; Bruckner, H.W. Ascorbic acid (vitamin C) improves the antineoplastic activity of doxorubicin, cisplatin, and paclitaxel in human breast carcinoma cells in vitro. Cancer Lett. 1996, 103, 183-189. [CrossRef]

80. Minotti, G.; Menna, P.; Salvatorelli, E.; Cairo, G.; Gianni, L. Anthracyclines: Molecular advances and pharmacologic developments in antitumor activity and cardiotoxicity. Pharmacol. Rev. 2004, 56, 185-229. [CrossRef] [PubMed]

81. Gewirtz, D. A critical evaluation of the mechanisms of action proposed for the antitumor effects of the anthracycline antibiotics adriamycin and daunorubicin. Biochem. Pharmacol. 1999, 57, 727-741. [CrossRef]

82. Dong, K.; Zhao, Z.Z.; Kang, J.; Lin, L.R.; Chen, W.T.; Liu, J.X.; Wu, X.L.; Lu, T.L. Cinnamaldehyde and Doxorubicin CoLoaded Graphene Oxide Wrapped Mesoporous Silica Nanoparticles for Enhanced MCF-7 Cell Apoptosis. Int. J. Nanomed. 2020, 15, 10285-10304. [CrossRef] 
83. Wang, S.; Konorev, E.A.; Kotamraju, S.; Joseph, J.; Kalivendi, S.; Kalyanaraman, B. Doxorubicin induces apoptosis in normal and tumor cells via distinctly different mechanisms: Intermediacy of $\mathrm{H}_{2} \mathrm{O}_{2}$-and p53-dependent pathways. J. Biol. Chem. 2004, 279, 25535-25543. [CrossRef]

84. Galadari, S.; Rahman, A.; Pallichankandy, S.; Thayyullathil, F. Reactive oxygen species and cancer paradox: To promote or to suppress? Free Radic. Biol. Med. 2017, 104, 144-164. [CrossRef] [PubMed]

85. Basak, D.; Punganuru, S.R.; Srivenugopal, K.S. Piperlongumine exerts cytotoxic effects against cancer cells with mutant p53 proteins at least in part by restoring the biological functions of the tumor suppressor. Int. J. Oncol. 2016, 48, 1426-1436. [CrossRef] [PubMed]

86. Lee, S.-N.; Kang, K.-J. The effect of blueberry on ROS accumulation and cell death in human normal breast epithelial (MCF10A) and breast cancer (MCF7) cells. Korean J. Food Nutr. 2008, 21, 416-424.

87. Kumar, R.; Saneja, A.; Panda, A.K. An Annexin V-FITC_Propidium Iodide-Based Method for Detecting Apoptosis in a Non-Small Cell Lung Cancer Cell Line. In Lung Cancer: Methods and Protocols; Santiago-Cardona, P.G., Ed.; Springer: New York, NY, USA, 2021; pp. 213-223.

88. Wadkins, R.M.; Jovin, T.M. Actinomycin D and 7-aminoactinomycin D binding to single-stranded DNA. Biochemistry 1991, 30, 9469-9478. [CrossRef] [PubMed]

89. Schmit, T.; Klomp, M.; Khan, M.N. An Overview of Flow Cytometry: Its Principles and Applications in Allergic Disease Research. Methods Mol. Biol. 2021, 2223, 169-182. [CrossRef]

90. Golbidi, S.; Botta, A.; Gottfred, S.; Nusrat, A.; Laher, I.; Ghosh, S. Glutathione administration reduces mitochondrial damage and shifts cell death from necrosis to apoptosis in ageing diabetic mice hearts during exercise. Br. J. Pharmacol. 2014, 171, 5345-5360. [CrossRef] [PubMed]

91. Franco, R.; Cidlowski, J.A. Apoptosis and glutathione: Beyond an antioxidant. Cell Death Differ. 2009, 16, 1303-1314. [CrossRef] [PubMed]

92. Czeczuga-Semeniuk, E.; Wołczyński, S.; Dabrowska, M.; Dziecioł, J.; Anchim, T. The effect of doxorubicin and retinoids on proliferation, necrosis and apoptosis in MCF-7 breast cancer cells. Folia Histochem. Cytobiol. 2004, 42, 221-227.

93. Sugimoto, K.; Tamayose, K.; Sasaki, M.; Hayashi, K.; Oshimi, K. Low-dose doxorubicin-induced necrosis in Jurkat cells and its acceleration and conversion to apoptosis by antioxidants. Br. J. Haematol. 2002, 118, 229-238. [CrossRef]

94. Adams, J.M.; Cory, S. The Bcl-2 protein family: Arbiters of cell survival. Science 1998, 281, 1322-1326. [CrossRef] [PubMed]

95. Tu, Y.; Renner, S.; Xu, F.; Fleishman, A.; Taylor, J.; Weisz, J.; Vescio, R.; Rettig, M.; Berenson, J.; Krajewski, S.; et al. BCL-X expression in multiple myeloma: Possible indicator of chemoresistance. Cancer Res. 1998, 58, 256-262. [PubMed]

96. Jaattela, M.; Benedict, M.; Tewari, M.; Shayman, J.A.; Dixit, V.M. Bcl-x and Bcl-2 inhibit TNF and Fas-induced apoptosis and activation of phospholipase A2 in breast carcinoma cells. Oncogene 1995, 10, 2297-2305. [PubMed]

97. Lima, R.T.; Martins, L.M.; Guimaraes, J.E.; Sambade, C.; Vasconcelos, M.H. Specific downregulation of bcl-2 and xIAP by RNAi enhances the effects of chemotherapeutic agents in MCF-7 human breast cancer cells. Cancer Gene Ther. 2004, 11, 309-316. [CrossRef] [PubMed]

98. Akar, U.; Chaves-Reyez, A.; Barria, M.; Tari, A.; Sanguino, A.; Kondo, Y.; Kondo, S.; Arun, B.; Lopez-Berestein, G.; Ozpolat, B. Silencing of Bcl-2 expression by small interfering RNA induces autophagic cell death in MCF-7 breast cancer cells. Autophagy 2008, 4, 669-679. [CrossRef] [PubMed]

99. Bui, N.L.; Pandey, V.; Zhu, T.; Ma, L.; Basappa; Lobie, P.E. Bad phosphorylation as a target of inhibition in oncology. Cancer Lett. 2018, 415, 177-186. [CrossRef]

100. Kumagai, A.; Dunphy, W.G. Claspin, a novel protein required for the activation of Chk1 during a DNA replication checkpoint response in Xenopus egg extracts. Mol. Cell 2000, 6, 839-849. [CrossRef]

101. Chini, C.C.; Chen, J. Human claspin is required for replication checkpoint control. J. Biol. Chem. 2003, 278, 30057-30062. [CrossRef]

102. Bianco, J.N.; Bergoglio, V.; Lin, Y.L.; Pillaire, M.J.; Schmitz, A.L.; Gilhodes, J.; Lusque, A.; Mazieres, J.; Lacroix-Triki, M.; Roumeliotis, T.I.; et al. Overexpression of Claspin and Timeless protects cancer cells from replication stress in a checkpointindependent manner. Nat. Commun. 2019, 10, 910. [CrossRef]

103. Shojaei, F.; Yazdani-Nafchi, F.; Banitalebi-Dehkordi, M.; Chehelgerdi, M.; Khorramian-Ghahfarokhi, M. Trace of survivin in cancer. Eur. J. Cancer Prev. 2019, 28, 365-372. [CrossRef]

104. Nestal de Moraes, G.; Vasconcelos, F.C.; Delbue, D.; Mognol, G.P.; Sternberg, C.; Viola, J.P.; Maia, R.C. Doxorubicin induces cell death in breast cancer cells regardless of Survivin and XIAP expression levels. Eur. J. Cell Biol. 2013, 92, 247-256. [CrossRef] [PubMed]

105. Siddiqa, A.; Long, L.M.; Li, L.; Marciniak, R.A.; Kazhdan, I. Expression of HER-2 in MCF-7 breast cancer cells modulates anti-apoptotic proteins Survivin and Bcl-2 via the extracellular signal-related kinase (ERK) and phosphoinositide-3 kinase (PI3K) signalling pathways. BMC Cancer 2008, 8, 129. [CrossRef]

106. Mitri, Z.; Constantine, T.; O'Regan, R. The HER2 Receptor in Breast Cancer: Pathophysiology, Clinical Use, and New Advances in Therapy. Chemother. Res. Pract. 2012, 2012, 743193. [CrossRef]

107. Jonsson, G.; Paulie, S.; Grandien, A. cIAP-2 block apoptotic events in bladder cancer cells. Anticancer Res. 2003, 23, 3311-3316.

108. Shao, F.; Wang, L.; Chu, X. Lonidamine induces apoptosis via endoplasmic reticulum stress response and down-regulating cIAP expression in human breast carcinoma MCF-7 cells. Nan Fang Yi Ke Da Xue Xue Bao 2015, 35, 883-887. 
109. Park, S.H.; Ham, S.; Kwon, T.H.; Kim, M.S.; Lee, D.H.; Kang, J.W.; Oh, S.R.; Yoon, D.Y. Luteolin induces cell cycle arrest and apoptosis through extrinsic and intrinsic signaling pathways in MCF-7 breast cancer cells. J. Environ. Pathol. Toxicol. Oncol. 2014, 33, 219-231. [CrossRef]

110. Verma, A.K.; Ahmad, I.; Yadav, P.; Rahmani, A.H.; Khan, B.; Alsahli, M.A.; Joshi, P.C.; Ahmad, H.; Ali Beg, M.M. Expression and Correlation of Cell-Free cIAP-1 and cIAP-2 mRNA in Breast Cancer Patients: A Study from India. J. Oncol. 2020, 2020, 3634825 [CrossRef] [PubMed]

111. Pluta, P.; Jeziorski, A.; Cebula-Obrzut, A.P.; Wierzbowska, A.; Piekarski, J.; Smolewski, P. Expression of IAP family proteins and its clinical importance in breast cancer patients. Neoplasma 2015, 62, 666-673. [CrossRef]

112. Yang, X.H.; Sladek, T.L.; Liu, X.; Butler, B.R.; Froelich, C.J.; Thor, A.D. Reconstitution of caspase 3 sensitizes MCF-7 breast cancer cells to doxorubicin- and etoposide-induced apoptosis. Cancer Res. 2001, 61, 348-354. [PubMed]

113. Yeruva, L.; Elegbede, J.A.; Carper, S.W. Methyl jasmonate decreases membrane fluidity and induces apoptosis through tumor necrosis factor receptor 1 in breast cancer cells. Anticancer Drugs 2008, 19, 766-776. [CrossRef] [PubMed]

114. Cui, Q.; Yu, J.H.; Wu, J.N.; Tashiro, S.; Onodera, S.; Minami, M.; Ikejima, T. P53-mediated cell cycle arrest and apoptosis through a caspase-3- independent, but caspase-9-dependent pathway in oridonin-treated MCF-7 human breast cancer cells. Acta Pharm. Sin. 2007, 28, 1057-1066. [CrossRef] [PubMed]

115. Zhang, G.P.; Lu, Y.Y.; Lv, J.C.; Ou, H.J. [Effect of ursolic acid on caspase-3 and PARP expression of human MCF-7 cells]. Zhongguo Zhong Yao Za Zhi 2006, 31, 141-144.

116. Yang, H.L.; Chen, C.S.; Chang, W.H.; Lu, F.J.; Lai, Y.C.; Chen, C.C.; Hseu, T.H.; Kuo, C.T.; Hseu, Y.C. Growth inhibition and induction of apoptosis in MCF-7 breast cancer cells by Antrodia camphorata. Cancer Lett. 2006, 231, 215-227. [CrossRef]

117. Chen, J.S.; Konopleva, M.; Andreeff, M.; Multani, A.S.; Pathak, S.; Mehta, K. Drug-resistant breast carcinoma (MCF-7) cells are paradoxically sensitive to apoptosis. J. Cell. Physiol. 2004, 200, 223-234. [CrossRef]

118. Wang, S.; He, M.; Li, L.; Liang, Z.; Zou, Z.; Tao, A. Cell-in-cell death is not restricted by caspase-3 deficiency in MCF-7 cells. J. Breast Cancer 2016, 19, 231. [CrossRef]

119. Janicke, R.U. MCF-7 breast carcinoma cells do not express caspase-3. Breast Cancer Res. Treat. 2009, 117, 219-221. [CrossRef]

120. Mackay, M.; Perez-Lopez, A.M.; Bradley, M.; Lilienkampf, A. Eliminating caspase-7 and cathepsin B cross-reactivity on fluorogenic caspase-3 substrates. Mol. Biosyst. 2016, 12, 693-696. [CrossRef] [PubMed]

121. Bhuyan, D.J.; Vuong, Q.V.; Bond, D.R.; Chalmers, A.C.; Bowyer, M.C.; Scarlett, C.J. Eucalyptus microcorys leaf extract derived HPLC-fraction reduces the viability of MIA PaCa-2 cells by inducing apoptosis and arresting cell cycle. Biomed. Pharmacother. 2018, 105, 449-460. [CrossRef]

122. Zhang, H.; Kim, J.K.; Edwards, C.A.; Xu, Z.; Taichman, R.; Wang, C.Y. Clusterin inhibits apoptosis by interacting with activated Bax. Nat. Cell Biol. 2005, 7, 909-915. [CrossRef] [PubMed]

123. Djeu, J.Y.; Wei, S. Clusterin and Chemoresistance. In Advances in Cancer Research; Academic Press: Cambridge, MA, USA, 2009; Volume 105, pp. 77-92.

124. Redondo, M.; Tellez, T.; Roldan, M.J.; Serrano, A.; Garcia-Aranda, M.; Gleave, M.E.; Hortas, M.L.; Morell, M. Anticlusterin treatment of breast cancer cells increases the sensitivities of chemotherapy and tamoxifen and counteracts the inhibitory action of dexamethasone on chemotherapy-induced cytotoxicity. Breast Cancer Res. Treat. 2007, 9, R86. [CrossRef] [PubMed]

125. Cai, Z.; Capoulade, C.; Moyret-Lalle, C.; Amor-Gueret, M.; Feunteun, J.; Larsen, A.K.; Paillerets, B.B.; Chouaib, S. Resistance of MCF7 human breast carcinoma cells to TNF-induced cell death is associated with loss of p53 function. Oncogene 1997, 15, 2817-2826. [CrossRef] [PubMed]

126. Whibley, C.; Pharoah, P.D.; Hollstein, M. p53 polymorphisms: Cancer implications. Nat. Rev. Cancer 2009, 9, 95-107. [CrossRef]

127. Lane, D.P.; Cheok, C.F.; Lain, S. p53-based cancer therapy. Cold Spring Harb. Perspect. Biol. 2010, 2, a001222. [CrossRef] [PubMed]

128. Xuan, H.; Li, Z.; Yan, H.; Sang, Q.; Wang, K.; He, Q.; Wang, Y.; Hu, F. Antitumor Activity of Chinese Propolis in Human Breast Cancer MCF-7 and MDA-MB-231 Cells. Evid. Based Complement. Altern. Med. 2014, 2014, 280120. [CrossRef]

129. Misir, S.; Aliyazicioglu, Y.; Demir, S.; Turan, I.; Hepokur, C. Effect of Turkish Propolis on miRNA Expression, Cell Cycle, and Apoptosis in Human Breast Cancer (MCF-7) Cells. Nutr. Cancer 2020, 72, 133-145. [CrossRef]

130. Liu, J.; Mao, W.; Ding, B.; Liang, C.S. ERKs/p53 signal transduction pathway is involved in doxorubicin-induced apoptosis in H9c2 cells and cardiomyocytes. Am. J. Physiol. Heart Circ. Physiol. 2008, 295, H1956-H1965. [CrossRef]

131. Kong, W.; Jiang, X.; Mercer, W.E. Downregulation of Wip-1 phosphatase expression in MCF-7 breast cancer cells enhances doxorubicin-induced apoptosis through p53-mediated transcriptional activation of Bax. Cancer Biol. Ther. 2009, 8, 555-563. [CrossRef]

132. Millour, J.; de Olano, N.; Horimoto, Y.; Monteiro, L.J.; Langer, J.K.; Aligue, R.; Hajji, N.; Lam, E.W. ATM and p53 regulate FOXM1 expression via E2F in breast cancer epirubicin treatment and resistance. Mol. Cancer Ther. 2011, 10, 1046-1058. [CrossRef]

133. Mohammad, N.; Singh, S.V.; Malvi, P.; Chaube, B.; Athavale, D.; Vanuopadath, M.; Nair, S.S.; Nair, B.; Bhat, M.K. Strategy to enhance efficacy of doxorubicin in solid tumor cells by methyl- $\beta$-cyclodextrin: Involvement of p53 and Fas receptor ligand complex. Sci. Rep. 2015, 5, 1-13. [CrossRef]

134. Lee, Y.K.; Thomas, S.N.; Yang, A.J.; Ann, D.K. Doxorubicin down-regulates Kruppel-associated box domain-associated protein 1 sumoylation that relieves its transcription repression on p21WAF1/CIP1 in breast cancer MCF-7 cells. J. Biol. Chem. 2007, 282, 1595-1606. [CrossRef] 
135. Liu, W.H.; Chang, L.S. Fas/FasL-dependent and -independent activation of caspase-8 in doxorubicin-treated human breast cancer MCF-7 cells: ADAM10 down-regulation activates Fas/FasL signaling pathway. Int. J. Biochem. Cell Biol. 2011, 43, 1708-1719. [CrossRef]

136. Li, S.; Zhou, Y.; Dong, Y.; Ip, C. Doxorubicin and selenium cooperatively induce fas signaling in the absence of Fas/Fas ligand interaction. Anticancer Res. 2007, 27, 3075-3082.

137. Wang, T.T.Y.; Jeng, J. Coordinated regulation of two TRAIL-R2/KILLER/DR5 mRNA isoforms by DNA damaging agents, serum and 17 $\beta$-estradiol in human breast cancer cells. Breast Cancer Res. Treat. 2000, 61, 87-96. [CrossRef] [PubMed]

138. Cui, D.D.; Huang, Y.; Mao, S.H.; Chen, S.C.; Qiu, M.; Ji, L.L.; Yi, C. Synergistic antitumor effect of TRAIL and adriamycin on the human breast cancer cell line MCF-7. Braz. J. Med. Biol. Res. 2009, 42, 854-862. [CrossRef]

139. Malin, D.; Chen, F.; Schiller, C.; Koblinski, J.; Cryns, V.L. Enhanced metastasis suppression by targeting TRAIL receptor 2 in a murine model of triple-negative breast cancer. Clin. Cancer Res. 2011, 17, 5005-5015. [CrossRef]

140. Pileczki, V.; Braicu, C.; Gherman, C.D.; Berindan-Neagoe, I. TNF- $\alpha$ gene knockout in triple negative breast cancer cell line induces apoptosis. Int. J. Mol. Sci. 2013, 14, 411-420. [CrossRef]

141. Mirzaei, S.; Zarrabi, A.; Hashemi, F.; Zabolian, A.; Saleki, H.; Azami, N.; Hamzehlou, S.; Farahani, M.V.; Hushmandi, K.; Ashrafizadeh, M.; et al. Nrf2 Signaling Pathway in Chemoprotection and Doxorubicin Resistance: Potential Application in Drug Discovery. Antioxidants 2021, 10, 349. [CrossRef]

142. Chun, K.S.; Kim, D.H.; Surh, Y.J. Role of Reductive versus Oxidative Stress in Tumor Progression and Anticancer Drug Resistance Cells 2021, 10, 758. [CrossRef] [PubMed]

143. Kim, H.K.; Kim, S.A.; Jung, E.K.; Lee, K.H.; Lee, J.K.; Kang, H.C.; Joo, Y.E.; Lim, S.C.; Yoon, T.M. Inhibitor of apoptosis protein Livin promotes tumor progression and chemoradioresistance in human anaplastic thyroid cancer. Oncol. Rep. 2021, 45, 1. [CrossRef] [PubMed]

144. Moradi-Marjaneh, R.; Paseban, M.; Moradi Marjaneh, M. Hsp70 inhibitors: Implications for the treatment of colorectal cancer. IUBMB Life 2019, 71, 1834-1845. [CrossRef] [PubMed]

145. Barnes, J.A.; Dix, D.J.; Collins, B.W.; Luft, C.; Allen, J.W. Expression of inducible Hsp70 enhances the proliferation of MCF-7 breast cancer cells and protects against the cytotoxic effects of hyperthermia. Cell Stress Chaperones 2001, 6, 316-325. [CrossRef]

146. Vaupel, P.; Mayer, A. Hypoxia in cancer: Significance and impact on clinical outcome. Cancer Metastasis Rev. 2007, 26, 225-239. [CrossRef] [PubMed]

147. Bos, R.; van der Groep, P.; Greijer, A.E.; Shvarts, A.; Meijer, S.; Pinedo, H.M.; Semenza, G.L.; van Diest, P.J.; van der Wall, E. Levels of hypoxia-inducible factor-1alpha independently predict prognosis in patients with lymph node negative breast carcinoma. Cancer 2003, 97, 1573-1581. [CrossRef] [PubMed]

148. Dhamad, A.E.; Zhou, Z.; Zhou, J.; Du, Y. Systematic Proteomic Identification of the Heat Shock Proteins (Hsp) that Interact with Estrogen Receptor Alpha (ERalpha) and Biochemical Characterization of the ERalpha-Hsp70 Interaction. PLoS ONE 2016, 11, e0160312. [CrossRef] [PubMed]

149. Glorieux, C.; Calderon, P.B. Catalase, a remarkable enzyme: Targeting the oldest antioxidant enzyme to find a new cancer treatment approach. Biol. Chem. 2017, 398, 1095-1108. [CrossRef]

150. Glorieux, C.; Calderon, P.B. Catalase down-regulation in cancer cells exposed to arsenic trioxide is involved in their increased sensitivity to a pro-oxidant treatment. Cancer Cell Int. 2018, 18, 24. [CrossRef] [PubMed]

151. De Moreno de LeBlanc, A.; LeBlanc, J.G.; Perdigon, G.; Miyoshi, A.; Langella, P.; Azevedo, V.; Sesma, F. Oral administration of a catalase-producing Lactococcus lactis can prevent a chemically induced colon cancer in mice. J. Med. Microbiol. 2008, 57, 100-105. [CrossRef]

152. Goh, J.; Enns, L.; Fatemie, S.; Hopkins, H.; Morton, J.; Pettan-Brewer, C.; Ladiges, W. Mitochondrial targeted catalase suppresses invasive breast cancer in mice. BMC Cancer 2011, 11, 191. [CrossRef]

153. Baker, A.M.; Oberley, L.W.; Cohen, M.B. Expression of antioxidant enzymes in human prostatic adenocarcinoma. Prostate 1997, 32, 229-233. [CrossRef]

154. Bostwick, D.G.; Alexander, E.E.; Singh, R.; Shan, A.; Qian, J.; Santella, R.M.; Oberley, L.W.; Yan, T.; Zhong, W.; Jiang, X.; et al Antioxidant enzyme expression and reactive oxygen species damage in prostatic intraepithelial neoplasia and cancer. Cancer 2000, 89, 123-134. [CrossRef]

155. Ho, J.C.M.; Zheng, S.; Comhair, S.A.A.; Farver, C.; Erzurum, S.C. Differential expression of manganese superoxide dismutase and catalase in lung cancer. Cancer Res. 2001, 61, 8578-8585.

156. Coursin, D.B.; Cihla, H.P.; Sempf, J.; Oberley, T.D.; Oberley, L.W. An immunohistochemical analysis of antioxidant and glutathione S-transferase enzyme levels in normal and neoplastic human lung. Histol. Histopathol. 1996, 11, 851-860.

157. Cullen, J.J.; Mitros, F.A.; Oberley, L.W. Expression of antioxidant enzymes in diseases of the human pancreas: Another link between chronic pancreatitis and pancreatic cancer. Pancreas 2003, 26, 23-27. [CrossRef] [PubMed]

158. Guner, G.; Islekel, H.; Oto, O.; Hazan, E.; Acikel, U. Evaluation of some antioxidant enzymes in lung carcinoma tissue. Cancer Lett. 1996, 103, 233-239. [CrossRef]

159. Kwei, K.A.; Finch, J.S.; Thompson, E.J.; Bowden, G.T. Transcriptional repression of catalase in mouse skin tumor progression. Neoplasia 2004, 6, 440-448. [CrossRef] [PubMed]

160. Lauer, C.; Volkl, A.; Riedl, S.; Fahimi, H.D.; Beier, K. Impairment of peroxisomal biogenesis in human colon carcinoma. Carcinogenesis 1999, 20, 985-989. [CrossRef] [PubMed] 
161. Marklund, S.L.; Westman, N.G.; Lundgren, E.; Roos, G. Copper- and zinc-containing superoxide dismutase, manganesecontaining superoxide dismutase, catalase, and glutathione peroxidase in normal and neoplastic human cell lines and normal human tissues. Cancer Res. 1982, 42, 1955-1961.

162. Oberley, T.D.; Sempf, J.M.; Oberley, L.W. Immunogold analysis of antioxidant enzymes in common renal cancers. Histol. Histopathol. 1996, 11, 153-160.

163. Subapriya, R.; Kumaraguruparan, R.; Ramachandran, C.R.; Nagini, S. Oxidant-antioxidant status in patients with oral squamous cell carcinomas at different intraoral sites. Clin. Biochem. 2002, 35, 489-493. [CrossRef]

164. Yoo, D.G.; Song, Y.J.; Cho, E.J.; Lee, S.K.; Park, J.B.; Yu, J.H.; Lim, S.P.; Kim, J.M.; Jeon, B.H. Alteration of APE1/ref-1 expression in non-small cell lung cancer: The implications of impaired extracellular superoxide dismutase and catalase antioxidant systems. Lung Cancer 2008, 60, 277-284. [CrossRef]

165. Glorieux, C.; Auquier, J.; Dejeans, N.; Sid, B.; Demoulin, J.B.; Bertrand, L.; Verrax, J.; Calderon, P.B. Catalase expression in MCF-7 breast cancer cells is mainly controlled by PI3K/Akt/mTor signaling pathway. Biochem. Pharmacol. 2014, 89, 217-223. [CrossRef]

166. Glorieux, C.; Dejeans, N.; Sid, B.; Beck, R.; Calderon, P.B.; Verrax, J. Catalase overexpression in mammary cancer cells leads to a less aggressive phenotype and an altered response to chemotherapy. Biochem. Pharmacol. 2011, 82, 1384-1390. [CrossRef] [PubMed]

167. Chinnaiyan, A.M.; O'Rourke, K.; Tewari, M.; Dixit, V.M. FADD, a novel death domain-containing protein, interacts with the death domain of Fas and initiates apoptosis. Cell 1995, 81, 505-512. [CrossRef]

168. Matsuyoshi, S.; Shimada, K.; Nakamura, M.; Ishida, E.; Konishi, N. FADD phosphorylation is critical for cell cycle regulation in breast cancer cells. Br. J. Cancer 2006, 94, 532-539. [CrossRef] [PubMed]

169. Suzuki, Y.; Takahashi-Niki, K.; Akagi, T.; Hashikawa, T.; Takahashi, R. Mitochondrial protease Omi/HtrA2 enhances caspase activation through multiple pathways. Cell Death Differ. 2004, 11, 208-216. [CrossRef] [PubMed]

170. Walle, L.V.; Lamkanfi, M.; Vandenabeele, P. The mitochondrial serine protease HtrA2/Omi: An overview. Cell Death Differ. 2008, 15, 453-460. [CrossRef]

171. Li, W.; Srinivasula, S.M.; Chai, J.; Li, P.; Wu, J.W.; Zhang, Z.; Alnemri, E.S.; Shi, Y. Structural insights into the pro-apoptotic function of mitochondrial serine protease HtrA2/Omi. Nat. Struct. Mol. Biol. 2002, 9, 436-441. [CrossRef]

172. Nestal de Moraes, G.; Delbue, D.; Silva, K.L.; Robaina, M.C.; Khongkow, P.; Gomes, A.R.; Zona, S.; Crocamo, S.; Mencalha, A.L.; Magalhaes, L.M.; et al. FOXM1 targets XIAP and Survivin to modulate breast cancer survival and chemoresistance. Cell Signal. 2015, 27, 2496-2505. [CrossRef]

173. Huang, Y.H.; Yeh, C.T. Functional Compartmentalization of HSP60-Survivin Interaction between Mitochondria and Cytosol in Cancer Cells. Cells 2019, 9, 23. [CrossRef]

174. Ghosh, J.C.; Dohi, T.; Kang, B.H.; Altieri, D.C. Hsp60 regulation of tumor cell apoptosis. J. Biol. Chem. 2008, $283,5188-5194$. [CrossRef] [PubMed]

175. Devarajan, A.; Su, F.; Grijalva, V.; Yalamanchi, M.; Yalamanchi, A.; Gao, F.; Trost, H.; Nwokedi, J.; Farias-Eisner, G.; FariasEisner, R.; et al. Paraoxonase 2 overexpression inhibits tumor development in a mouse model of ovarian cancer. Cell Death Dis. 2018, 9, 392. [CrossRef]

176. Muoio, M.G.; Talia, M.; Lappano, R.; Sims, A.H.; Vella, V.; Cirillo, F.; Manzella, L.; Giuliano, M.; Maggiolini, M.; Belfiore, A.; et al. Activation of the S100A7/RAGE Pathway by IGF-1 Contributes to Angiogenesis in Breast Cancer. Cancers 2021, 13, 621. [CrossRef] [PubMed]

177. Biello, F.; Platini, F.; D’Avanzo, F.; Cattrini, C.; Mennitto, A.; Genestroni, S.; Martini, V.; Marzullo, P.; Aimaretti, G.; Gennari, A. Insulin/IGF Axis in Breast Cancer: Clinical Evidence and Translational Insights. Biomolecules 2021, 11, 125. [CrossRef] [PubMed]

178. Christopoulos, P.F.; Corthay, A.; Koutsilieris, M. Aiming for the Insulin-like Growth Factor-1 system in breast cancer therapeutics. Cancer Treat. Rev. 2018, 63, 79-95. [CrossRef]

179. Christopoulos, P.F.; Msaouel, P.; Koutsilieris, M. The role of the insulin-like growth factor-1 system in breast cancer. Mol. Cancer 2015, 14, 43. [CrossRef]

180. Ford, D.; Easton, D.F. The genetics of breast and ovarian cancer. Br. J. Cancer 1995, 72, 805-812. [CrossRef]

181. Wooster, R.; Weber, B.L. Breast and ovarian cancer. N. Engl. J. Med. 2003, 348, 2339-2347. [CrossRef]

182. Simard, J.; Tonin, P.; Durocher, F.; Morgan, K.; Rommens, J.; Gingras, S.; Samson, C.; Leblanc, J.F.; Belanger, C.; Dion, F.; et al. Common origins of BRCA1 mutations in Canadian breast and ovarian cancer families. Nat. Genet. 1994, 8, 392-398. [CrossRef]

183. Liu, X.; Kim, C.N.; Yang, J.; Jemmerson, R.; Wang, X. Induction of apoptotic program in cell-free extracts: Requirement for dATP and cytochrome c. Cell 1996, 86, 147-157. [CrossRef]

184. Kharbanda, S.; Pandey, P.; Schofield, L.; Israels, S.; Roncinske, R.; Yoshida, K.; Bharti, A.; Yuan, Z.M.; Saxena, S.; Weichselbaum, R.; et al. Role for Bcl-xL as an inhibitor of cytosolic cytochrome C accumulation in DNA damage-induced apoptosis. Proc. Natl. Acad. Sci. USA 1997, 94, 6939-6942. [CrossRef]

185. Garcia-Heredia, J.M.; Diaz-Quintana, A.; Salzano, M.; Orzaez, M.; Perez-Paya, E.; Teixeira, M.; De la Rosa, M.A.; Diaz-Moreno, I. Tyrosine phosphorylation turns alkaline transition into a biologically relevant process and makes human cytochrome c behave as an anti-apoptotic switch. J. Biol. Inorg. Chem. 2011, 16, 1155-1168. [CrossRef]

186. Polyak, K.; Lee, M.H.; Erdjument-Bromage, H.; Koff, A.; Roberts, J.M.; Tempst, P.; Massague, J. Cloning of p27Kip1, a cyclindependent kinase inhibitor and a potential mediator of extracellular antimitogenic signals. Cell 1994, 78, 59-66. [CrossRef] 
187. Chu, I.M.; Hengst, L.; Slingerland, J.M. The Cdk inhibitor p27 in human cancer: Prognostic potential and relevance to anticancer therapy. Nat. Rev. Cancer 2008, 8, 253-267. [CrossRef]

188. Chu, I.; Sun, J.; Arnaout, A.; Kahn, H.; Hanna, W.; Narod, S.; Sun, P.; Tan, C.K.; Hengst, L.; Slingerland, J. p27 phosphorylation by Src regulates inhibition of cyclin E-Cdk2. Cell 2007, 128, 281-294. [CrossRef]

189. Chappuis, P.O.; Kapusta, L.; Begin, L.R.; Wong, N.; Brunet, J.S.; Narod, S.A.; Slingerland, J.; Foulkes, W.D. Germline BRCA1/2 mutations and p27(Kip1) protein levels independently predict outcome after breast cancer. J. Clin. Oncol. 2000, 18, 4045-4052. [CrossRef]

190. Wilson, C.A.; Ramos, L.; Villasenor, M.R.; Anders, K.H.; Press, M.F.; Clarke, K.; Karlan, B.; Chen, J.J.; Scully, R.; Livingston, D.; et al. Localization of human BRCA1 and its loss in high-grade, non-inherited breast carcinomas. Nat. Genet. 1999, 21, 236-240. [CrossRef]

191. Holt, J.T.; Thompson, M.E.; Szabo, C.; Robinson-Benion, C.; Arteaga, C.L.; King, M.C.; Jensen, R.A. Growth retardation and tumour inhibition by BRCA1. Nat. Genet. 1996, 12, 298-302. [CrossRef] [PubMed]

192. Mueller, C.R.; Roskelley, C.D. Regulation of BRCA1 expression and its relationship to sporadic breast cancer. Breast Cancer Res. Treat. 2003, 5, 45-52. [CrossRef] [PubMed]

193. Jacinto, F.V.; Esteller, M. Mutator pathways unleashed by epigenetic silencing in human cancer. Mutagenesis 2007, 22, 247-253. [CrossRef] [PubMed]

194. Lee, J.H.; Paull, T.T. ATM activation by DNA double-strand breaks through the Mre11-Rad50-Nbs1 complex. Science 2005, 308, 551-554. [CrossRef] [PubMed]

195. Gatei, M.; Young, D.; Cerosaletti, K.M.; Desai-Mehta, A.; Spring, K.; Kozlov, S.; Lavin, M.F.; Gatti, R.A.; Concannon, P.; Khanna, K. ATM-dependent phosphorylation of nibrin in response to radiation exposure. Nat. Genet. 2000, 25, 115-119. [CrossRef]

196. Paull, T.T.; Rogakou, E.P.; Yamazaki, V.; Kirchgessner, C.U.; Gellert, M.; Bonner, W.M. A critical role for histone H2AX in recruitment of repair factors to nuclear foci after DNA damage. Curr. Biol. 2000, 10, 886-895. [CrossRef]

197. Stucki, M.; Clapperton, J.A.; Mohammad, D.; Yaffe, M.B.; Smerdon, S.J.; Jackson, S.P. MDC1 directly binds phosphorylated histone H2AX to regulate cellular responses to DNA double-strand breaks. Cell 2005, 123, 1213-1226. [CrossRef]

198. Stewart, G.S.; Wang, B.; Bignell, C.R.; Taylor, A.M.; Elledge, S.J. MDC1 is a mediator of the mammalian DNA damage checkpoint. Nature 2003, 421, 961-966. [CrossRef] [PubMed]

199. Wang, B.; Matsuoka, S.; Carpenter, P.B.; Elledge, S.J. 53BP1, a mediator of the DNA damage checkpoint. Science 2002, 298, 1435-1438. [CrossRef] [PubMed]

200. Wilson, K.A.; Stern, D.F. NFBD1/MDC1, 53BP1 and BRCA1 have both redundant and unique roles in the ATM pathway. Cell Cycle 2008, 7, 3584-3594. [CrossRef]

201. Escribano-Diaz, C.; Orthwein, A.; Fradet-Turcotte, A.; Xing, M.; Young, J.T.; Tkac, J.; Cook, M.A.; Rosebrock, A.P.; Munro, M.; Canny, M.D.; et al. A cell cycle-dependent regulatory circuit composed of 53BP1-RIF1 and BRCA1-CtIP controls DNA repair pathway choice. Mol. Cell 2013, 49, 872-883. [CrossRef]

202. Zimmermann, M.; Lottersberger, F.; Buonomo, S.B.; Sfeir, A.; de Lange, T. 53BP1 regulates DSB repair using Rif1 to control $5^{\prime}$ end resection. Science 2013, 339, 700-704. [CrossRef]

203. Jiang, M.; Huang, O.; Xie, Z.; Wu, S.; Zhang, X.; Shen, A.; Liu, H.; Chen, X.; Wu, J.; Lou, Y.; et al. A novel long non-coding RNA-ARA: Adriamycin resistance-associated. Biochem. Pharmacol. 2014, 87, 254-283. [CrossRef]

204. Chamieh, H.; Ballut, L.; Bonneau, F.; Le Hir, H. NMD factors UPF2 and UPF3 bridge UPF1 to the exon junction complex and stimulate its RNA helicase activity. Nat. Struct. Mol. Biol. 2008, 15, 85-93. [CrossRef]

205. Lykke-Andersen, J.; Shu, M.D.; Steitz, J.A. Human Upf proteins target an mRNA for nonsense-mediated decay when bound downstream of a termination codon. Cell 2000, 103, 1121-1131. [CrossRef]

206. Gehring, N.H.; Kunz, J.B.; Neu-Yilik, G.; Breit, S.; Viegas, M.H.; Hentze, M.W.; Kulozik, A.E. Exon-junction complex components specify distinct routes of nonsense-mediated mRNA decay with differential cofactor requirements. Mol. Cell 2005, 20, 65-75. [CrossRef] [PubMed]

207. Mamoor, S. UPF2 is a differentially expressed gene in brain metastatic human breast cancer. OSFPREPRINTS 2021. [CrossRef]

208. Xu, C.; Chen, H.; Wang, X.; Gao, J.; Che, Y.; Li, Y.; Ding, F.; Luo, A.; Zhang, S.; Liu, Z. S100A14, a member of the EF-hand calciumbinding proteins, is overexpressed in breast cancer and acts as a modulator of HER2 signaling. J. Biol. Chem. 2014, $289,827-837$. [CrossRef]

209. Tanaka, M.; Ichikawa-Tomikawa, N.; Shishito, N.; Nishiura, K.; Miura, T.; Hozumi, A.; Chiba, H.; Yoshida, S.; Ohtake, T.; Sugino, T. Co-expression of S100A14 and S100A16 correlates with a poor prognosis in human breast cancer and promotes cancer cell invasion. BMC Cancer 2015, 15, 53. [CrossRef]

210. Ravipati, A.S.; Zhang, L.; Koyyalamudi, S.R.; Jeong, S.C.; Reddy, N.; Bartlett, J.; Smith, P.T.; Shanmugam, K.; Munch, G.; Wu, M.J.; et al. Antioxidant and anti-inflammatory activities of selected Chinese medicinal plants and their relation with antioxidant content. BMC Complement. Altern. Med. 2012, 12, 173. [CrossRef]

211. Ahmed, S.A.; Gogal, R.M., Jr.; Walsh, J.E. A new rapid and simple non-radioactive assay to monitor and determine the proliferation of lymphocytes: An alternative to [3H]thymidine incorporation assay. J. Immunol. Methods 1994, 170, 211-224. [CrossRef]

212. Farag, O.M.; Abd-Elsalam, R.M.; Ogaly, H.A.; Ali, S.E.; El Badawy, S.A.; Alsherbiny, M.A.; Li, C.G.; Ahmed, K.A. Metabolomic Profiling and Neuroprotective Effects of Purslane Seeds Extract Against Acrylamide Toxicity in Rat's Brain. Neurochem. Res. 2021, 46, 819-842. [CrossRef] [PubMed] 
213. Azouz, A.A.; Ali, S.E.; Abd-Elsalam, R.M.; Emam, S.R.; Galal, M.K.; Elmosalamy, S.H.; Alsherbiny, M.A.; Hassan, B.B.; Li, C.G.; El Badawy, S.A. Modulation of steroidogenesis by Actaea racemosa and vitamin C combination, in letrozole induced polycystic ovarian syndrome rat model: Promising activity without the risk of hepatic adverse effect. Chin. Med. 2021, 16, 36. [CrossRef] [PubMed]

214. Chou, T.C. Drug combination studies and their synergy quantification using the Chou-Talalay method. Cancer Res. 2010, 70, 440-446. [CrossRef]

215. Chou, T.; Martin, N. CompuSyn for Drug Combinations: PC Software and User's Guide: A Computer Program for Quantitation of Synergism and Antagonism in Drug Combinations, and the Determination of IC50 and ED50 and LD50 Values; ComboSyn: Paramus, NJ, USA, 2005.

216. Chou, T.-C.; Martin, N. The mass-action law-based new computer software, CompuSyn, for automated simulation of synergism and antagonism in drug combination studies. Exp. Mol. Ther. 2007, 67, 637.

217. Zagidullin, B.; Aldahdooh, J.; Zheng, S.; Wang, W.; Wang, Y.; Saad, J.; Malyutina, A.; Jafari, M.; Tanoli, Z.; Pessia, A.; et al. DrugComb: An integrative cancer drug combination data portal. Nucleic Acids Res. 2019, 47, W43-W51. [CrossRef] [PubMed]

218. Abràmoff, M.D.; Magalhães, P.J.; Ram, S.J. Image processing with ImageJ. Biophotonics Int. 2004, 11, 36-42.

219. Chong, J.; Soufan, O.; Li, C.; Caraus, I.; Li, S.; Bourque, G.; Wishart, D.S.; Xia, J. MetaboAnalyst 4.0: Towards more transparent and integrative metabolomics analysis. Nucleic Acids Res. 2018, 46, W486-W494. [CrossRef] [PubMed]

220. Szklarczyk, D.; Morris, J.H.; Cook, H.; Kuhn, M.; Wyder, S.; Simonovic, M.; Santos, A.; Doncheva, N.T.; Roth, A.; Bork, P. The STRING database in 2017: Quality-controlled protein-protein association networks, made broadly accessible. Nucleic Acids Res. 2016, gkw937. [CrossRef]

221. Fabregat, A.; Jupe, S.; Matthews, L.; Sidiropoulos, K.; Gillespie, M.; Garapati, P.; Haw, R.; Jassal, B.; Korninger, F.; May, B.; et al. The Reactome Pathway Knowledgebase. Nucleic Acids Res. 2018, 46, D649-D655. [CrossRef] [PubMed]

222. Reimand, J.; Arak, T.; Adler, P.; Kolberg, L.; Reisberg, S.; Peterson, H.; Vilo, J. g: Profiler-A web server for functional interpretation of gene lists (2016 update). Nucleic Acids Res. 2016, 44, W83-W89. [CrossRef]

223. Reimand, J.; Isserlin, R.; Voisin, V.; Kucera, M.; Tannus-Lopes, C.; Rostamianfar, A.; Wadi, L.; Meyer, M.; Wong, J.; Xu, C.; et al. Pathway enrichment analysis and visualization of omics data using g:Profiler, GSEA, Cytoscape and EnrichmentMap. Nat. Protoc. 2019, 14, 482-517. [CrossRef] [PubMed]

224. Kamburov, A.; Cavill, R.; Ebbels, T.M.; Herwig, R.; Keun, H.C. Integrated pathway-level analysis of transcriptomics and metabolomics data with IMPaLA. Bioinformatics 2011, 27, 2917-2918. [CrossRef]

225. Perez-Riverol, Y.; Csordas, A.; Bai, J.; Bernal-Llinares, M.; Hewapathirana, S.; Kundu, D.J.; Inuganti, A.; Griss, J.; Mayer, G.; Eisenacher, M.; et al. The PRIDE database and related tools and resources in 2019: Improving support for quantification data. Nucleic Acids Res. 2019, 47, D442-D450. [CrossRef] [PubMed] 